\title{
Graziela Kunsch
}

\section{Não caber}

Início da pesquisa Estou na frente da câmera mas a minha cabeça está atrás dela

$\mathrm{ou}$

A performance da diretora

ou

A performance da crítica

São Paulo, 2016 

Graziela Kunsch

Não caber

Início da pesquisa Estou na frente da câmera mas

a minha cabeça está atrás dela

ou

A performance da diretora

$\mathrm{ou}$

A performance da crítica

Tese apresentada ao Programa de Pós-

Graduação em Meios e Processos Audiovisuais

da Escola de Comunicações e Artes da

Universidade de São Paulo, na Área de

Concentração História, Teoria e Crítica, como

parte integrante dos requisitos para obtenção do

título de Doutora em Meios e Processos

Audiovisuais, sob a orientação do Prof. Dr.

Rubens Luis Ribeiro Machado Jr.

São Paulo, 2016 
Autorizo a reprodução e divulgação total ou parcial deste trabalho, por qualquer meio convencional ou eletrônico, para fins de estudo e pesquisa, desde que citada a fonte.

Catalogação na Publicação

Serviço de Biblioteca e Documentação

Escola de Comunicações e Artes da Universidade de São Paulo Dados fornecidos pelo(a) autor(a)

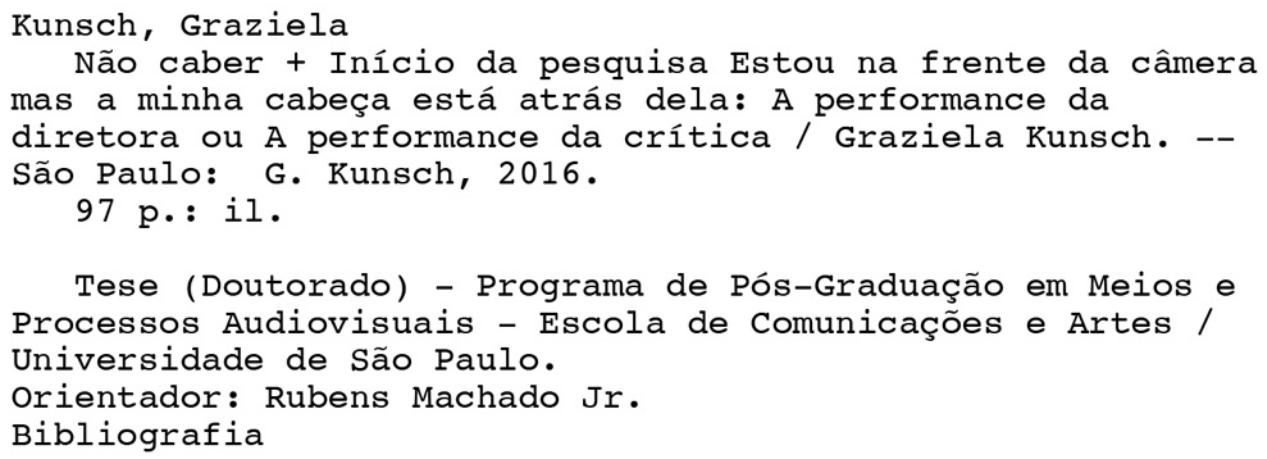

1. Performance 2. Documentário 3. Crítica Institucional 4. Autoimagem 5. Graziela Kunsch I. Machado Jr., Rubens II. Título.

CDD 21.ed. - 700 
Julgamento:

Presidente da banca:

Prof. Dr. Rubens Luis Ribeiro Machado Jr.

Instituição: ECA-USP

Assinatura:

Banca examinadora:

Prof(a) Dr(a)

Instituição:

Assinatura:

$\operatorname{Prof}(a) \operatorname{Dr}(a)$

Instituição:

Assinatura:

Prof(a) Dr(a)

Instituição:

Assinatura:

Prof(a) Dr(a)

Instituição:

Assinatura:

São Paulo, 



\section{RESUMO}

1) A pesquisa artística não pode se subordinar à obediência acadêmica.

2) A presença de cineastas como personagens de seus próprios filmes, interpretando seus próprios papeis, talvez seja o mais próximo que o cinema chega da performance. Essa presença, de caráter supostamente documental, se dá sempre com a consciência que o realizador/a realizadora tem da câmera, de modo que exerce o duplo papel de atorencenador (como Renato Cohen descreve o performer) ou protagonista-observador de sua própria atuação (Jorge Glusberg). A frase que dá título à esta parte da pesquisa - "Estou na frente da câmera mas a minha cabeça está atrás dela" - foi dita por Jean-Luc Godard durante a sua participação no filme Quarto 666, de Wim Wenders.

3) A crítica do artista tende a ser sempre individual; a verdadeira crítica só pode ser coletiva.

Palavras-chave:

Performance; Documentário \& Performance; Crítica; Crítica Institucional; Reflexividade; Autoimagem; Efeito-câmera; Graziela Kunsch 



\section{ABSTRACT}

1) Artistic research cannot be subordinated to academic obedience.

2) The presence of filmmakers as characters in their own movies, playing their own roles, is perhaps the closest cinema gets to performance. This presence, supposedly documentary-oriented, always occurs with the awareness that the director has of the camera, so that he/she performs the dual role of actor-director (as Renato Cohen describes the performer) or actor-observer of his own performance (Jorge Glusberg). The sentence used as title of this part - "I'm in front of the camera but my head is behind it" - was said by Jean-Luc Godard while participating in the film Room 666, by Wim Wenders.

3) Artist's criticism tends to be always individual; the real criticism has to be collective.

Key-words:

Performance; Documentary \& Performance; Critique; Institutional Critique; Reflexivity; Self-Image; Camera-effect; Graziela Kunsch 

Eu queria, de verdade, ter feito uma tese de doutorado normal. Assim como, em diversas aberturas de exposição, olhei para a minha obra e desejei ter feito uma obra mais bem acabada. Desejei que meu vídeo fosse projetado grande em uma sala escura, de modo que atraísse total atenção do espectador ou da espectadora. Mas há qualquer coisa que me pede para falhar.

Foi assim também no meu trabalho de graduação em Artes Plásticas, em 2001. Tendo sido uma aluna muito produtiva, inicialmente imaginei organizar uma exposição retrospectiva de todos os trabalhos que considerei relevantes ao longo do curso, junto de uma publicação impressa. No lugar, terminei o curso com um "Esboço de filme" e com um texto que ocupava uma única folha A4. Era um trabalho novo, um esboço, e me interessava mais debater as dúvidas em torno dessa obra nascendo do que obras que eu considerava bem resolvidas. Um professor se retirou da minha banca, pois não aceitou ver meu novo trabalho, um vídeo com menos de vinte minutos de duração, somente poucos dias antes da defesa. Ele argumentou que eu tive um ano inteiro para desenvolver um trabalho final e que não existia isso de criar um novo trabalho no último momento.

No mestrado em Cinema, em 2008, a minha dissertação foi intitulada como um projeto, "Projeto Mutirão". Ao longo da dissertação falo também em "filme não realizável" e "prática documentária". Hoje o Projeto Mutirão segue sendo ativado e transformado, a ponto de ser um dos objetos da presente tese, como se verá mais adiante.

Agora, na finalização do meu doutorado, em meio ao sofrimento de não ter atuado como penso que as outras pessoas esperam que eu atue, ou, pior, como eu mesma penso que deveria ter atuado, comecei a rememorar a minha atuação como professora. 
Comecei a dar aulas muito nova, na mesma escola em que me formei atriz. Nessa escola os cursos com crianças e adolescentes tinham duração anual e, ao final do ano, cada turma deveria apresentar um espetáculo teatral. O procedimento mais comum era o primeiro semestre ser focado em jogos e improvisações teatrais e o segundo semestre dedicado aos ensaios da peça final. O meu processo com as turmas era diferente. As peças eram sempre criações coletivas (no sentido de não serem adaptações de textos existentes) e, já no primeiro dia do curso, eu dizia que iríamos "estar criando" - assim mesmo, no gerúndio, para dar ênfase tanto no tempo presente como na continuidade da ação - em todos nossos encontros, entre fevereiro e dezembro. A dramaturgia da peça seria tão somente amarrar as diferentes criações cotidianas conforme o processo avançasse.

Essa dramaturgia acabava tendo uma mão pesada minha; era eu quem assumia a responsabilidade pela estrutura geral das peças, ainda que essa estrutura fosse debatida coletivamente. Mas as cenas eram todas criações das alunas e dos alunos. As aulas eram dividas em dois momentos, com um intervalo no meio. No primeiro momento eu conduzia aquecimento e exercícios teatrais/corporais e trazia referências relacionadas ao nosso tema de investigação (mobilizando também a literatura, a música, a dança e as artes visuais). No segundo momento eu fazia uma proposta de improvisação coletiva e deixava a sala. Eu me sentava em um banco ao lado da porta fechada e a turma tinha que se entender como grupo, criando uma longa cena coletiva, em que todos eram, ao mesmo tempo, atores e diretores. Na escola uma psicóloga entrava vez ou outra nas salas para acompanhar o desenvolvimento de cada criança/adolescente e, mais de uma vez, flagrou-me nessa situação. Enquanto em outras turmas os processos de ensaio (de repetição) da peça final estavam adiantados, nas minhas turmas tudo era ainda experimentação. Isso deixava a psicóloga preocupada e mesmo eu sofria, até o dia 
da apresentação, mas eu confiava nesse processo e hoje tenho a clareza de que aqueles foram meus melhores momentos como professora.

Depois de passar anos na escola de Teatro e já formada em Artes Plásticas, tive a oportunidade de dar aulas em uma universidade pública, como professora substituta. Ali fui responsável pelas aulas de Desenho II, Gravura e Estudos especificos em arte contemporânea. Antes de "Desenho II" as turmas tinham passado por aulas de "Desenho I". Para o primeiro encontro dessa disciplina eu havia pedido que cada aluno e cada aluna trouxesse até três trabalhos de sua produção, de modo que eu pudesse conhecê-los. Eram duas turmas diferentes, que haviam feito "Desenho I" com dois professores diferentes. Em uma das turmas todos os três trabalhos eram sempre iguais: "este era o exercício de luz e sombra; este de perspectiva; este do barbante". Na outra turma cada aluna e cada aluno já começava a esboçar uma linguagem própria: uma menina desenhava colando seus pelos pubianos sobre fotografias, por exemplo.

Não me interessa aqui debater a questão da técnica do desenho versus um desenho conceitual ou um pensamento em desenho (e eu garanto a vocês que os exercícios de luz e sombra, de perspectiva e do barbante nada tinham de treinamento técnico, eram apenas ruins mesmo). O que ficou claro para mim é que os alunos da primeira turma não estavam trabalhando para eles mesmos, mas para o professor. Não faziam seus próprios trabalhos, mas os trabalhos do professor. Que muito provavelmente nada significavam para esse professor, que estava apenas cumprindo o que ele julgou apropriado a uma aula de Desenho.

Com o propósito de estimular uma busca por uma linguagem/expressão pessoal, escolhi as formas autorretrato/autobiografia para trabalhar com esse grupo. Pedi que cada um e cada uma providenciasse um caderno. Este caderno não seria um caderno de croquis - até poderia ser, também - mas a ideia é que funcionasse como uma espécie de diário das aulas 
de Desenho. Esse caderno poderia ser usado durante as nossas aulas, para anotações, mas, pouco a pouco, deveria ser um diário de seus processos artísticos. Não teriam que me mostrar esse caderno, mas era importante que confiassem na proposta e que o caderno fosse cultivado. A cada encontro eu levava uma referência de autorretrato/autobiografia para discutirmos e uma solução formal (primeiro um retrato simples, depois um retrato em díptico, um retrato em série, um livro... Não me recordo de todas as etapas/formas propostas). A cada semana as alunas e os alunos faziam trabalhos individuais, a partir das referências e discussões em sala, e conversávamos. Foi interessante notar que, muito rapidamente, as formas fechadas foram dando origem a novas formas. As proposições eram tão somente proposições, um ponto de partida. Uma base para quem ainda não tinha ferramentas suficientes para criar. $\mathrm{Na}$ metade do curso tinha aluna fazendo performance. Outra instalação. Outra tornou seu próprio caderno/diário obra. Do desenho com o fio de barbante passamos ao desenho como uma extensão do nosso corpo, do nosso gesto, o nosso rastro no mundo.

A terceira experiência como professora que trago aqui (que não foi a terceira, nem a última, mas apenas mais uma entre diferentes experiências), foi em um curso técnico de Fotografia. Fui convidada para dar as aulas de Projeto. A expectativa da escola era que eu contemplasse editais públicos de cultura e metodologia de projeto escrito. Com raras exceções, ninguém nessas turmas tinha muita inclinação para a escrita, ou gosto pela escrita. Estavam no penúltimo semestre do curso e, assim como a turma de Desenho, não tinham nenhum trabalho mais autoral para me mostrar no primeiro dia de aula. Seus portfólios eram quase todos iguais, tanto na forma de encadernação como nos conteúdos, ainda que algumas imagens se destacassem. A grande maioria daquelas pessoas havia buscado esse curso porque gostava de fotografar, de maneira amadora. Ao entrar no curso, muito rapidamente aprenderam a se enquadrar no que era uma fotografia social "correta", o que era uma 
fotografia jornalística "correta", o que era uma fotografia de arquitetura "correta" e assim por diante. Pensei que meu papel, antes de orientá-los na redação e no financiamento de projetos, era estimular que tivessem um projeto. Um projeto que não salvariam em seus computadores na pasta "Grazi", mas em uma pasta com seus nomes próprios, ou com o título do projeto. Um projeto que não se encerraria nos meses de curso comigo ou em páginas de papel de um trabalho obrigatório, mas que existiria para além das nossas aulas e para além da escola. Não vou descrever aqui a estratégia utilizada dessa vez, mas quero enfatizar que, para mim, era muito mais importante a aluna ou o aluno terminar o curso com um princípio de projeto, uma ideia, um desejo, que eu sabia que iria continuar de algum modo a partir dali, do que cumprindo um texto burocrático, sobre um projeto sem sentido, apenas para ser aprovada ou aprovado. E isso era dito com clareza, era estimulado.

Até aqui eu nunca tinha escrito sobre meus processos como professora. O que tenho comigo são programas iniciais de aulas (dos casos em que foi obrigatório apresentar um programa) e auto-avaliações finais de alunas e alunos - um conjunto de perguntas que peço que respondam sobre o curso e sobre seu próprio aprendizado, sendo a pergunta mais importante se saem de nosso processo diferentes de como entraram.

Colocando-me na situação de aluna, doutoranda, termino esses quatro anos diferente de como comecei. Menos pelo processo de doutoramento, mais pela vida, mas também pelo doutoramento. Lá atrás eu tinha uma expectativa de finalmente terminar com algo muito consistente. Eu chamava meu novo trabalho de "Ensaio de filme", de certo modo repetindo a recusa em fechar a forma já presente em meu esboço da graduação e no meu projeto de mestrado. Mas eu acreditava de verdade que desta vez eu teria um filme muito bem acabado para mostrar. Hoje, terminar meu doutorado com algo consistente assumiu novo significado. 
Não tive bolsa de estudos e, sem bolsa, não pude ter dedicação exclusiva à pesquisa. Além disso, a vida me convocou de corpo inteiro em diversos momentos ao longo dos últimos quatro anos, por exemplo quando da minha participação, como artista, na $31^{a}$ Bienal de São Paulo e no $33^{\circ}$ Panorama de Arte Brasileira, entre outras exposições relevantes no contexto artístico brasileiro e internacional; e em junho de 2013, quando escolhi estar junto do movimento social que ajudei a criar, o Movimento Passe Livre. Se faço doutorado como uma etapa para me tornar uma melhor professora, não poderia ignorar todo o aprendizado que vem da luta.

Minha atividade política e minha prática artística se fundiram mais de uma vez ao longo do período do doutorado e estou anexando à tese dois produtos dessa atuação: o folder da mostra CINEMA PERIGOSO DIVINO MARAVILHOSO, curadoria que realizei no MIS - Museu da Imagem e do Som, em 2012, em torno do cinema indígena produzido hoje no Brasil; e a quinta edição da revista Urbânia, focada em práticas de educação democrática, um de meus projetos na $31^{a}$ Bienal. $\mathrm{O}$ folder pode funcionar melhor como um complemento ao foco desta pesquisa de doutorado, dado que ali abordei as noções de "perigoso", "divino" e "maravilhoso" como uma superação da fronteira entre autenticidade e teatralidade, que para mim é uma das características própria da performance, talvez tema principal desta tese.

Foi importante trazer a revista Urbânia 5 para cá também, por causa de nosso momento histórico. Há poucos dias, durante a redação da tese, aconteceu mais uma manifestação fascista na Av. Paulista, a maior de todas até hoje. Neste exato momento, poucos dias depois, novas manifestações de fascismo e eu apreensiva com o que está por vir. O único conforto é estarem se aglomerando ao redor do prédio da Fiesp, não no vão do MASP/da Lina (somos todos em estética como em política). 
Apresentar a revista é uma forma de eu me posicionar, de assumir o lugar onde me encontro. Quem chegar a folhear o anexo, poderá compreender as minhas intenções. Além disso, na minha dissertação de mestrado, em 2008, foi anexado o terceiro número da revista Urbânia. Considero significativa a continuidade e sobrevivência desse projeto editorial, que produz pensamento fora dos padrões acadêmicos e para além da universidade.

O texto que segue terá por vezes mais a cara de projeto que de tese consumada. Quero evidenciar o inacabamento próprio do pensamento se formando, de modo a abrir espaço para a reflexão e a colaboração de quem estiver lendo. Tive uma inspiração bastante tardia (um ano após a minha qualificação) de qual exatamente poderia ser a minha contribuição teórica/crítica/artística mais interessante no tema da presença de diretores em seus próprios filmes, assumindo seus próprios papéis, e resolvi seguir essa inspiração, ainda que careça de mais tempo de leitura, estudo de filmes e redação.

Neste sentido devo agradecer especialmente ao meu orientador, $\mathrm{Ru}-$ bens, por me permitir criar, até o último momento, como eu fazia com as alunas e os alunos de teatro. A nossa parceria de orientador-orientanda irá completar já doze anos e nesse período pude testemunhar, como sua assistente, algumas de suas aulas de Análise da produção audiovisual contemporânea e Crítica do audiovisual, raros momentos de vida e debate público no Curso Superior do Audiovisual da ECA-USP. Seus esforços em manter, quase semanalmente, os encontros públicos de nosso grupo de pesquisa (Grupo História da Experimentação no Cinema e na Crítica) também refletem a importância de professores como ele para a universidade não se encerrar nela mesma. 
Agradeço a Celina, minha analista, que me ajudou a me permitir fazer a tese final deste jeito e não de outro; aos meus pais, Margarida e Waldemar, cujas expectativas em torno do doutorado poderão dar lugar a novas conversas; a minha irmã Clarice, que abriu a última semana de redação com uma mensagem de apoio; a minha irmã Adriana e a minha sobrinha Clara, pela própria existência da Clarinha em nossas vidas; ao Jorge e ao Fabio, um velho e um novo amigo, por terem lido e comentado o meu texto enquanto ele se formava. Aos alunos do workshop Performance e desobediência, quando formulei algumas ideias que estão aqui, em especial Beano, que ampliou minha bibliografia.

Ao Tom, meu aluno em 2001, peça Estar de pé diante de, hoje cineasta pela ECA, que bem no momento em que panelas e buzinas dificultam tanto meu equilíbrio emocional e minha escrita, comenta no Facebook: "Que bom que nossos caminhos se cruzaram e tivemos a oportunidade de ter muito mais que uma professora de teatro".

Ao Mateus, pela aula sobre a autoimagem de Godard. A Ilana, por compartilharmos a paixão por G.H. (e é daí que vem o título da peça com a turma do Tom).

Agradeço imensamente a todas as pessoas que, em algum momento, reagiram a textos públicos meus, e tiveram suas reações publicadas, na terceira parte da tese, entre eles dois colegas da pós, cujas pesquisas dialogam com a minha: Francis e Patricia. Ao Dani, cuja presença em minha vida não cabe aqui, por termos sobrevivido.

Finalmente, quero dizer que sempre gostei mais das introduções que das conclusões. Em um mundo dominado por pensamento burocrático e que cobra da gente eficiência e produtividade, aprendi que o mais autêntico e original que tenho a oferecer como intelectual é a minha inadequação, o meu fracasso. 
Parte 1

Não caber

Meninas,

não sei bem por que, mas vocês me pediram que eu escrevesse algo sobre a experiência dos rejeitados no nono Salão da Bahia, que aconteceu em 2002. Fiquei tentando lembrar o que eu poderia ter falado sobre essa experiência em um dos nossos dois encontros, o primeiro, em torno da revista Urbânia, e não consegui. Talvez sequer tenha falado e vocês tenham tido contato com essa história dos rejeitados por outros caminhos.

Escolhi não perguntar qual exatamente é o interesse de vocês nessa experiência, para me permitir fazer um texto muito simples, que aborde tão somente o meu principal aprendizado junto aos rejeitados.

Estava buscando e-mails daquela época - toda a conversa entre os rejeitados se deu, principalmente, através de uma troca diária e intensa de e-mails - e acabei encontrando o início de um texto que nunca cheguei a escrever, que seria sobre os rejeitados. Esse esboço de texto começava assim:

No primeiro capitulo de A condição humana, Hannah Arendt afirma que "a tarefa e a grandeza potencial dos mortais têm a ver com sua capacidade de produzir coisas - obras e feitos e palavras - que mereceriam pertencer e, pelo menos até certo ponto, pertencem à eternidade”. E conta que Sócrates nunca deu forma escrita a seus pensamentos, pois "por mais que um pensador se preocupe com a eternidade, no instante em que se dispõe a escrever os seus pensamentos deixa de estar fundamentalmente preocupado com a eternidade e volta 
sua atenção para a tarefa de legar aos pósteros algum vestígio deles". Mais adiante, Arendt coloca que a experiência do eterno foi conceitualizada como "aquilo que é agora".

Hoje não me espanta que eu nunca tenha conseguido dar continuidade a esse texto. Escrever de maneira objetiva sobre os rejeitados seria fazer aquilo que, de outras maneiras, nos recusamos a fazer. Se fizemos história, foi paradoxalmente porque escolhemos não deixar muitos vestígios no espaço do Salão da Bahia. Recusamos mostrar nossos rostos (quem buscar um catálogo do salão irá entender), recusamos caber em determinadas categorias. Quebramos as regras desde o momento da nossa inscrição no salão, cujas novas regras foram por nós definidas. Questionamos a soberania do júri e convertemos os antes critérios de exclusão em uma acolhida irrestrita.

Vocês sugerem que eu faça um texto de aproximadamente nove páginas, um artigo. Eu até teria a capacidade de fazê-lo; o tempo ideal e a vontade nem tanto. Eu não seria fiel ao espírito dos rejeitados se atendesse a essa demanda.

Escrevo esta carta para vocês desde a cidade do Porto, onde ontem participei de um pequeno debate sobre educação. Na ocasião falei sobre a importância de, como educadores, aprendermos a fracassar. Sobre a necessidade de não sermos tão eficientes; de abrir espaço para o tempo do outro. E li um pequeno texto do meu amigo Jorge Menna Barreto, chamado "A sobrevivência do espanto".

Hoje vou fazer um exercício parecido e encerrar esta singela contribuição à revista com outro texto do Jorge, que sempre acha um jeito bonito de dizer as coisas. Trata-se de um e-mail aos rejeitados de treze anos atrás, dia 31 de outubro de 2002. Naquele momento nós trocamos muitas cartas impressas entre nós (eu estava vivendo fora do Brasil, 
durante uma residência artística de sete meses) e enviamos muitas cartas ao MAM Bahia (inclusive a nossa "técnica" nas fichas do salão não era desenho, pintura, instalação ou vídeo, mas a palavra "correspondência”). Estávamos apenas começando a usar a internet e a nos organizar em rede, de modo que mesmo nossos e-mails eram um pouco como cartas.

Agradeço pelo interesse de vocês e deixo um forte abraço em cada uma.

Grazi

De: Jorge Menna Barreto

Destinatários: rejeitados

Assunto: uma mão decepada

Data: $31 / 10 / 2002$

tem um artista que se chama andreas slominski que fez uma exposição assim: ele abriu um buraco na parede da galeria, colocou ali a mão de um ser humano decepada, e tapou com massa. de um jeito que não se sabia mais onde estava a mão. pois o remendo foi perfeito.

a crítica que escrevia sobre esse trabalho perguntou-se se a sala estava vazia. e chegou à conclusão que não. que a sala estava preenchida. pela história. pelo rumor. pelo mistério de se aquilo teria acontecido ou não já que não havia provas. cheio de provocação. convite pra pensar sobre confiança. sobre visibilidade. sobre fato e prova. sobre a galeria. sobre a mão decepada. sobre manualidade. E sobre a rejeição. a rejeição de ocupar o espaço conforme o esperado. E nessa desestabilização cria-se justamente o território fértil pra instaurar essas questões. espaço não-retiniano. o rejeitados está 
acontecendo. e se deixarmos uma sala vazia, ela já não estará mais vazia. ela já nos contém e já somos rumores. já somos história. já temos uma atitude. todos esses emails, todos os projetos produzidos por nós. toda essa reflexão não cabe no salão. não cabe. o ideal dos rejeitados também não cabe. rejeitados são sempre rejeitados porque não cabem nos critérios. podemos criar uma representação de tudo isso que estamos vivenciando e colocar a ponta do iceberg lá. mas a atitude rejeitados só se completará na ação de rejeitar. acredito. e penso que o que se quer aqui não é fazer um trabalho para apresentar no salão da bahia. mas promover uma discussão bem mais ampla sobre o sistema e os critérios dos salões, uma crítica mais profunda a todo o sistema de premiações que de nada apóiam a cultura brasileira. enfim, acho que uma não ocupação na bahia estaria repleta dessas convocações. somos muito mais do que esses grupos. somos, como disse alguém, mil seiscentos e tantos rejeitados somente nesse salão. e somos muito mais se formos contar socialmente. e não somos representáveis. na verdade, acho esse vazio preenchido de protesto como se fosse o tal gozo proposto por mariana. uma não afirmação desse salão. se participarmos como esperam, o salão se pretende tão inclusivo a ponto de incluir a nossa proposta! quando na verdade é uma grande mentira. eles nunca nos incluiram, porque nem temos forma! e por isso que não chegamos a um acordo. os rejeitados são formless informes aformais incapturáveis. recusam-se a toda a formalização por sua própria condição. e não vai ser o salão da bahia que vai conseguir esse heróico ato de nos formatar! não temos rosto. somos a mosca na sopa, o dente do tubarão, o filho que 
ainda não veio, o início, o fim e o meio! risos! a não ser que a gente represente, e eles $t b$, e a quem estaremos enganando? a todos os rejeitados!!!! impossível! impossível! a nossa não ocupação espacial é uma ocupação politica. um ato vazio de forma e cheio de atitude politica. política no sentido mais extenso de discussão, diálogo, crítica, pensamento. que é isso que estamos fazendo aqui. isso é política. pode ser que deixando esse espaço vazio, nada disso aconteça. pode ser que seja uma grande bosta e que ninguém se sinta provocado a pensar nessas questões. pode ser. pode ser ridículo. pode ser romantismo. eu quero correr o risco. eu não caibo nesse email. 
Toda vez que recebo uma demanda como artista - seja de um curador, de uma instituição etc. - acabo buscando um modo de "não caber" totalmente na proposta, às vezes até mesmo frustrando expectativas. Não por desrespeito, muito pelo contrário. Levo as coisas tão a sério que não posso evitar problematizá-las, entendendo as próprias proposições como parte ativa da minha pesquisa, da minha prática intelectual e artística.

São muitos os projetos que posso dar como exemplo desse modo de operar e descrições/imagens/textos críticos desses projetos podem ser vistos no meu website:

naocaber.org

Para trazer um exemplo para o corpo presente da tese, em 2011 fui convidada a participar de uma exposição chamada "Cavalos de Tróia", com curadoria de Fernando Cocchiarale e Pedro França. Essa exposição era uma das cinco curadorias que compunham o projeto Caos e Efeito, organizado pelo Itaú Cultural para refletir sobre o que fora a arte brasileira nas últimas décadas e também sobre o que seria a arte brasileira nas próximas décadas (!). Todos os curadores-chefe convidados eram homens. Interessada no recorte curatorial "Cavalos de Tróia”, que acolheu obras/documentações de artistas históricos que respeito muito como Anna Bella Geiger, Grupo Rex, Nervo Óptico, Daniel Santiago e Paulo Bruscky, entre outros, num primeiro momento concordei, feliz, em apresentar vídeos do Projeto Mutirão ali. Imaginei também realizar conversas específicas do projeto com a equipe do educativo e com o público ao longo de toda duração da exposição, até saber que nós artistas não receberíamos nenhuma remuneração por nosso trabalho. A montagem da exposição foi bastante acelerada e já haviam até mesmo construído uma pequena sala para a projeção de meus vídeos. Chamei um dos curadores para uma conversa e informei que, no lugar do Projeto 
Mutirão, eu gostaria de expor um pequeno quadrinho. No meio de um papel branco, escrevi uma frase à mão, à lápis: "Prefiro não fazer". Meu quadrinho foi acolhido pela curadoria e a salinha imaginada para os vídeos foi usada para abrigar uma vitrine da artista Alice Miceli.

Na sequência desse gesto (o quadrinho, a frase) escrevi a base de uma carta à instituição e convoquei as/os aproximadamente 70 artistas participantes das cinco exposições para reivindicarmos a nossa remuneração. A carta teve adesão quase total e a nossa demanda foi ouvida. Recebemos o valor simbólico de R $\$ 1.000,00$ por nossa participação.

Para deixar claro que a recusa presente em "Prefiro não fazer" e a carta coletiva foram uma resposta crítica precisa ao projeto curatorial "Cavalos de Tróia", ou o resultado de eu levar a proposição dos curadores muito a sério, uso a apresentação da exposição no site do Itaú Cultural para explicar/contextualizar minha obra:

Fernando Cocchiarale - em cocuradoria com Pedro França demonstrou em seu recorte curatorial a crítica embutida nos processos de concepção, produção da obra e sua inserção no sistema artístico. Essa proposta, que vai contra a noção mercadológica da arte e que ganhou força no Brasil nas décadas de 1960 e 1970, procurou questionar os fundamentos desse sistema, sua ideologia e a crença no objeto artístico como o único resultado aceitável do trabalho do artista ${ }^{1}$.

\footnotetext{
${ }^{1}$ Ver http://www.itaucultural.org.br/explore/artes-visuais/projetos/hotsite/?id=60158 . O texto curatorial completo pode ser lido em http://portalicuploads.s3.amazonaws.com/wp-content/uploads/2012/08/Sobre-Cavalosde-Troia.pdf. Último acesso em 18/3/2016.
} 


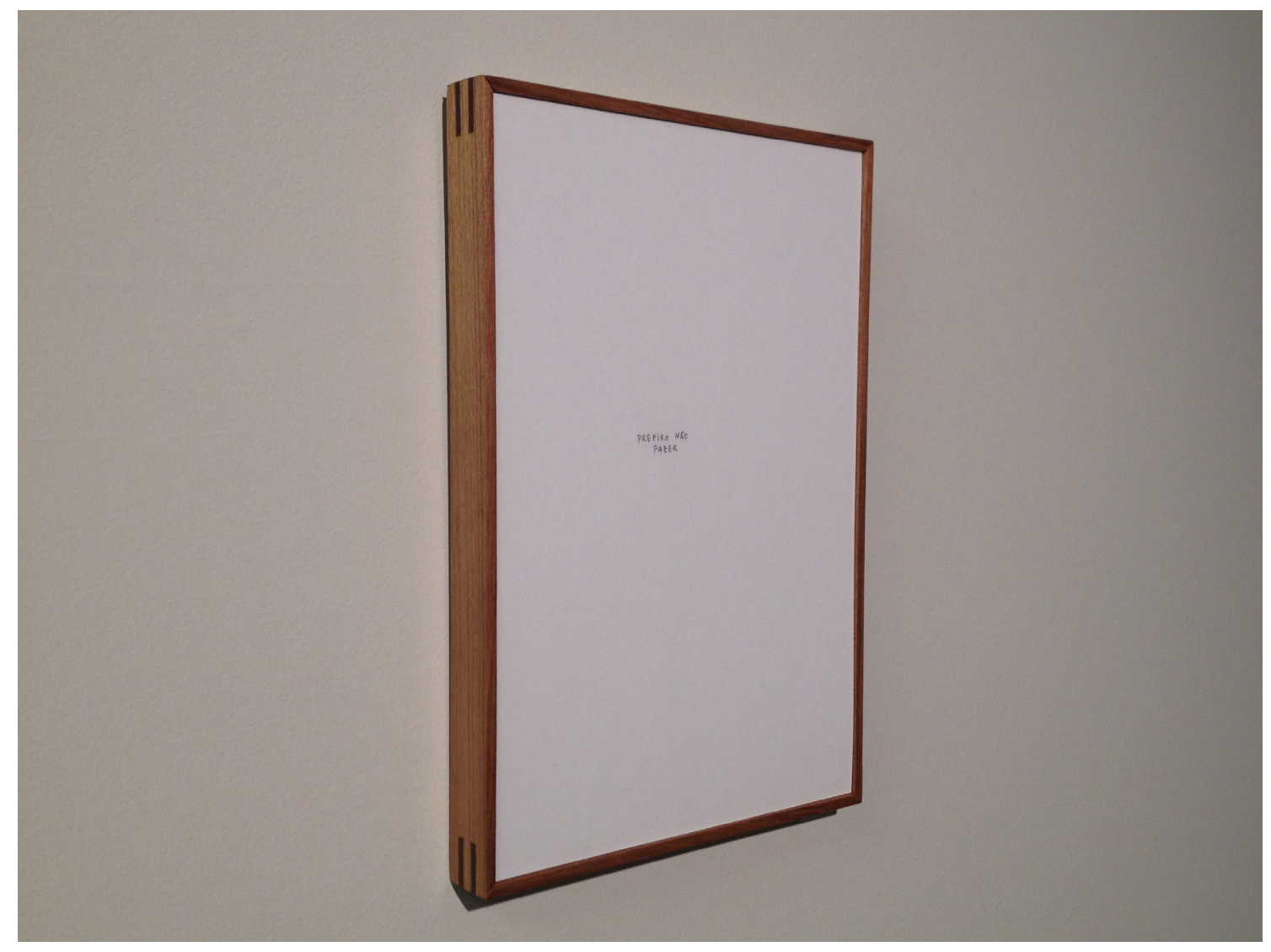

Sem título (Prefiro não fazer). Graziela Kunsch, 2011 
O website naocaber.org foi a forma que encontrei de trazer ao meu doutorado todos os projetos que realizei que considero relevantes na minha trajetória/na minha formação. Ainda que a grande maioria de meus projetos possa ser contada, sem grande perda de substância, cada um possui uma entrada/um contexto diferente e há muitos vídeos. Seria monótono descrever verbalmente um projeto após o outro aqui na tese, de modo que somente alguns serão destacados. Meu pedido é que cada membro da banca se reúna comigo, numa conversa um pra um, antes da data da defesa, para eu apresentar o funcionamento geral do website e escolher alguns projetos para mostrar, conforme a conversa caminhar. A partir daí quem se sentir estimulado poderá criar seu próprio percurso pelo website, que além dos projetos artísticos reúne meus textos críticos, como se verá mais adiante. Aqui, na parte escrita da tese, o mais importante é chamar atenção para o que diferentes projetos meus guardam em comum: uma disposição performática e crítica ${ }^{2}$.

Fazer essa afirmação hoje parece fácil, mas levei muito tempo - quase duas décadas - para ter essa clareza sobre a presença permanente $d a$ performance na minha prática e a minha performance como uma forma de crítica. E essa percepção veio principalmente a partir da recepção do meu trabalho.

A primeira pista que tive foi em 2007, na noite de abertura da minha exposição Não há nada para ver, no SESC Pinheiros. Um grande amigo da minha época de teatro, Ruy Cortez, estava no SESC para ver uma peça teatral. A exposição acontecia no mesmo andar do auditório de teatro e acabamos nos encontrando. Ele entrou na sala da exposição, viu o espaço sem nada nas paredes, com bancos/poltronas para pessoas se sentarem em roda, leu o título do trabalho, leu um material impresso

\footnotetext{
${ }^{2}$ Além da obra Sem título (Prefiro não fazer), buscar por exemplo, no website, as obras Graziela Kunsch não existe (2000); Rampa para moradores de rua (2008); Não ação (2011); Projeto Mutirão no MAR (2013); e O público de fora (2014).
} 
que anunciava o programa de quatro conversas abertas que aconteceriam ali, riu e me disse: "Você nunca abandonou o teatro"!

Ouvir isso do Ruy teve um impacto grande em mim porque houve um momento na nossa trajetória, no meio de 2002, em que ele escolheu abandonar nosso grupo de performance - o Núcleo Performático Subterrânea - e eu escolhi abandonar o teatro. Foi quando deixei de dar aulas no Teatro-Escola Célia Helena e na Casa do Teatro e deixei de trabalhar como atriz. Recém-formada em Artes Plásticas, minhas experimentações em performance haviam se radicalizado tanto ${ }^{3}$ que para mim era impossível retornar ao palco.

O Núcleo Performático Subterrânea foi um grupo paulistano que realizou performances e experimentações de rua radicais no começo dos anos 2000 e que hoje resiste na atuação solitária de algumas/alguns integrantes, como eu. As performances do Subterrânea não tinham planejamento nem registro e eu costumava dizer que não eram atuação, mas uma reação à atuação cotidiana das pessoas. Espontaneidade; improvisação; não-atuação clássica; provocação; nova relação entre "atores" e público - ambos na condição de atuantes -; e relação corporal com a cidade eram alguns dos expedientes vislumbrados e, acredito, alcançados pela nossa prática. Antes era tudo muito experimental e intuitivo, mas hoje posso contextualizar o Subterrânea em meio às práticas de outros artistas brasileiros que buscaram performatizar o cotidiano, como Oswald de Andrade, Flavio de Carvalho, Lygia Clark, grupo Viajou sem passaporte e Augusto Boal (este no caso específico do teatro invisivel $^{4}$ ). Recuso-me a verbalizar as coisas que fazíamos, de modo

\footnotetext{
${ }^{3}$ Buscar como referência, no website, as obras Nightshot 3 (2000) e Escolha uma (2002).

${ }^{4}$ Nas palavras de Boal, "O teatro invisível consiste na apresentação de uma cena em um ambiente que não seja o teatro, diante de pessoas que não são espectadores. O lugar pode ser um restaurante, uma calçada, um mercado, um trem, uma fila etc. As pessoas que testemunham a cena são aquelas que
} 
que vou me limitar a dizer que a nossa proposta era criar situações de agora a partir de um aqui inseguro. Havia sempre um perigo na nossa (não) atuação.

$\mathrm{Na}$ época o Ruy precisou se afastar do Subterrânea porque ficava muito abalado com a sua própria performance. Ele dizia: "a sensação que vivencio quando estou fazendo performance em meio ao Subterrânea é a de estar muito inteiro, vivo, como se eu saísse de um estado de letargia e de repente estivesse acordado, na lucidez da realidade" ${ }^{\prime 5}$. Em um certo momento ele temeu que, se seguisse nas nossas experimentações, deixaria de acreditar em todas as outras formas de teatro, e por isso optou por se afastar. Do meu lado, passei por crise parecida, mas escolhi me afastar do teatro, ainda que eu estivesse engajada em um teatro mais crítico e na prática de criações coletivas, como dito na minha introdução, o que não deveria ser entendido como "espetáculo". Encerrei meus compromissos com a escola e, não por acaso, fui morar sete meses em Paris, com uma bolsa-residência, para estudar a Internacional Situacionista.

Retomando o raciocínio anterior, quando o Ruy me disse aquilo - que eu nunca teria abandonado o teatro - comecei a me dar conta de o quanto muitos dos meus projetos eram cênicos, no sentido de serem acontecimentos, de precisarem da minha presença junto a outras pessoas para ganhar forma. Não eram bem teatro - e a presença é mais da ordem da performance que do teatro -, mas muito provavelmente vinham de toda a minha vivência em teatro. $\mathrm{O}$ próprio projeto de eu ter

estão lá por acaso. Durante o espetáculo, essas pessoas não devem ter a menor ideia que se trata de um espetáculo, porque isso os tornaria espectadores". Trecho de texto publicado na revista Urbânia 2. São Paulo: Editora Pressa, 2002. p. 20-23. Versão escaneada da revista disponível em http://urbania4.org/wp-content/uploads/2010/10/urbania2 leitura baixa.pdf $\mathrm{Na}$ época nós editores da Urbânia tomamos conhecimento desse texto em inglês, em um livro sobre performances de rua radicais. Como não localizamos o original em português, Rodolfo Valente traduziu do inglês.

${ }^{5}$ De seu depoimento na revista Urbânia 2. São Paulo: Editora Pressa, 2002. 
aberto a casa onde eu morava como uma "residência pública" (Casa da Grazi), entre 2001 e 2007, tendo acolhido diversas residências de coletivos de artistas e de ativistas, e compartilhado objetos pessoais e vida cotidiana com tanta gente, muito provavelmente vinha da minha vida fortemente coletiva anterior, junto a pessoas de teatro.

As outras pistas para entender tudo o que faço como performance vieram na recepção de meus trabalhos nos anos seguintes. Quase qualquer coisa que eu fizesse - podia ser um desenho, uma palestra, um vídeo as pessoas comentavam como "performance". Em outras palavras, eu podia dar uma palestra formal, inclusive lendo um texto, e as pessoas começariam a debater meu trabalho afirmando "Esta performance que você fez hoje...". (Não era eu quem dizia "estou fazendo uma performance", mas o público percebia desse modo).

Ocorre que performance é um conceito extremamente contestado, como propõe Marvin Carlson logo no início da sua introdução crítica à performance. Ele cita as autoras Mary Strine, Beverly Long e Mary Hopkins como responsáveis por aplicar a noção de conceito contestado, de W.B.Gallie, à performance ${ }^{6}$. Segundo Gallie,

\begin{abstract}
Reconhecer um dado conceito como essencialmente questionado implica reconhecer usos rivais desse contexto (como os que ele mesmo repudia) não apenas como algo logicamente possível e humanamente provável, mas também como algo sendo de valor crítico potencial permanente, para o próprio uso ou a interpretação do conceito em questão ${ }^{7}$.
\end{abstract}

Não por acaso, a introdução e a conclusão do livro de Carlson são intituladas com a mesma pergunta - "O que é performance?" - e abrem com um parágrafo idêntico. $\mathrm{O}$ autor explica:

\footnotetext{
${ }^{6}$ CARLSON, Marvin. Performance: uma introdução crítica. Belo Horizonte: UFMG, 2010.

${ }^{7}$ GALLIE, W.B. Philosophy and the historical understanding. Nova Iorque: Schoken Books, 1964. Grifo meu.
} 
A performance, por sua própria natureza, resiste a conclusões assim como resiste à definições, fronteiras e limites tão úteis à escrita acadêmica tradicional e às estruturas acadêmicas. Pode ser útil, então, considerar essas observações como uma espécie de anticonclusão a um estudo dessa antidisciplina enquadrada no modo de autorreflexividade, um modo que caracteriza muito da consciência performática moderna ou pósmoderna, se alguém está falando de performance teatral, performance social, performance etnográfica ou antropológica, performance linguística, ou, no presente caso, a performance de escrever um estudo acadêmico.

Desde a época do Subterrânea criei minhas próprias definições de performance. Sabia que havia uma série de usos do termo, mas somente as minhas definições me satisfaziam. Para mim performance era a nossa prática "desavisada", no sentido de não anunciada, não ensaiada, que provocava alguma quebra no cotidiano. Que existia no (não) limite entre ser e atuar, normalidade e loucura, ficção e documentário. Eu não aceitava que certas encenações, pelo simples fato de a pessoa estar no seu próprio papel e não no papel de um personagem, fossem chamadas de performance. Hoje respeito mais as diferentes aplicações práticas do termo e aprendi que o instigante é a performance seguir recusando uma fácil categorização, seguir como um conceito democrático e inconclusivo. Pela minha própria experiência aprendi que a performance pode assumir formas as mais variadas - seja a prática radical do Núcleo Performático Subterrânea; ou um pequeno desenho/escrito/gesto como foi o quadrinho "Prefiro não fazer"; ou as conversas do Projeto Mutirão, que serão brevemente descritos na segunda parte da tese; ou o texto que abre a terceira parte, de uma palestra que dei no MAC-USP.

A única diferença é que, se na época do Núcleo Performático Subterrânea eu falava em reação à atuação cotidiana das pessoas, hoje falo mais em respostas críticas. Para mim, hoje, performance e crítica se confundem. Ambas implicam trazer à luz certos processos, nem sempre tão visíveis. A expressão “não caber” talvez seja isso; a resposta crítica que problematiza - ou revela, abala, alarga - limites. Um verbo porque um procedimento, um modo de (não) fazer. 
Início da pesquisa Estou na frente da câmera mas a minha cabeça está atrás dela

ou

A performance da diretora

"Nada a fazer". Assim começa o diálogo entre os personagens Estragon e Vladimir na peça Esperando Godot, de Samuel Beckett. A sensação de impotência sugerida na primeira frase é presente durante toda a obra e, ao final, quando os dois esboçam uma última desistência (desistência do ato de esperar por Godot, que nunca chega), a rubrica nos informa que eles não se movem.

O filme Esperando Telê $\left(1993-2007^{8}\right)$ poderia também ser resumido como uma dupla de personagens (os realizadores da obra, Rubens Rewald e Tales Ab'Sáber) à espera de alguém que nunca chega (o técnico de futebol Telê Santana, com quem desejam realizar uma entrevista). Mas, diferentemente dos sofridos Estragon e Vladimir - e também diferentemente de cineastas que se viram imobilizados pela Era Collor, época imediatamente anterior à captação das imagens que constituem o filme ${ }^{9}$-, Rubens e Tales estão em movimento. O mote seria "tudo a

\footnotetext{
${ }^{8}$ A edição do filme data de 2007, mas as imagens foram captadas em 1993 e 1994 e o filme reflete aquele momento histórico.

${ }^{9}$ Explica minha ex-colega de ECA Daniela Pinto Senador, em artigo no jornal da USP de setembro de 2003: "De todos os momentos de crise que entrecortaram a história da cultura brasileira e, em especial, a história do cinema, um deles foi um tanto quanto estarrecedor. Começou com a ascensão de Fernando Collor de Mello à presidência da República, em 1990, e se estendeu até setembro de 1992. Valendo-se de diversas medidas provisórias, Collor autorizou que fossem extintas leis de incentivos culturais e órgãos culturais da União, dentre eles a Empresa Brasileira de Filmes (Embrafilme), o Conselho Nacional de Cinema (Concine) e a Fundação do Cinema Brasileiro (FCB). Com isso, por dois anos o Brasil teve a sua produção cinematográfica praticamente estagnada". Ler mais em http://www.usp.br/jorusp/arquivo/2003/jusp657/pag1213.htm .
} 
fazer", ainda que compactuem com os personagens de Beckett o fato de serem extremamente desastrados, nas suas repetidas e frustradas tentativas de falar com Telê.

Ocorre que falar com Telê resulta não ser tão importante; o processo de busca por ele é que se revela mais interessante. Exatamente como ocorre no futebol-arte, como ficou caracterizado o futebol da seleção de 1982, treinada por Telê, que tinha jogadores incríveis como Zico, Sócrates, Falcão, Toninho Cerezo e Júnior, e que perdeu a Copa. Para quem aprecia a arte, o mais importante é o jogo (o processo, a brincadeira, o filme), não ganhar ou perder.

Ainda que Telê não conceda uma entrevista aos realizadores, ele está presente em quase todo o filme. São imagens que os cineastas registraram durante treinos do São Paulo Futebol Clube (ainda que não da mesma posição autorizada da grande imprensa, que também é enquadrada pela câmera dos cineastas); de Telê dando autógrafos, possivelmente após uma partida ou após um treino; e, na sua maioria, imagens apropriadas de aparições de Telê em programas de televisão, por exemplo sendo entrevistado pela jornalista Marília Gabriela (ela sim teve acesso ao técnico para uma longa entrevista).

Dentre as imagens da TV destaco uma sequência de três cenas que mais chamou a minha atenção, de três depoimentos diferentes, em que Telê menciona a sua busca por perfeição:

Eu sou um homem que procuro... Eu não sou perfeito não, mas procuro atingir, tudo que eu faço, eu procuro atingir a perfeição. É o que eu digo aos jogadores: a perfeição, talvez ela não exista, mas nós temos sempre que estar correndo, procurando aproximar-nos dela.

Chegar à perfeição é impossivel, mas aproximar-se dela não é impossivel. A gente pode chegar bem próximo dela. 
É dificil alcançar a perfeição, mas não é dificil aproximar-se dela. Então é isso que eu faço. Eu não sou perfeito, mas procuro me aproximar da perfeição.

No filme, Pelé é apresentado por Telê como o atleta que atingiu essa almejada perfeição do mundo dos esportes: "[Pelé] chutava, cabeceava, chutava com a esquerda, com a direita, dominava, armava, finalizava, jogava em qualquer posição; então esse foi o [jogador] perfeito". Após essa fala há um longo momento dedicado a Pelé, no meio do filme. Testemunhamos seu milésimo gol, que parecia já ter toda uma cobertura midiática armada antes de acontecer e, na sequência, uma música e voz dramáticas contam como foi a despedida de Pelé do dentro de campo:

Ele tentou, num último esforço, um último gol. A cabeçada foi acompanhada de uma insuportável emoção e de uma terrivel dor no coração. Carlos defendeu. Pelé foi caminhando para o meio de campo. Esperou a bola passar por ele, como ela sempre passou. Pela primeira vez em sua vida a agarrou com as duas mãos. Se ajoelhou. Abriu os braços em forma de cruz. Virou para os quatro lados do estadinho da Vila. E começou a chorar. Arrancou a camisa do corpo e iniciou a volta olímpica. Estava terminada a mais maravilhosa carreira que Deus poderia ter criado. Quando Pelé sumiu pela boca do túnel e a grade fechou a entrada, o povo ficou em silêncio. Como se o jogo, que recomeçava, não tivesse público. O futebol brasileiro teve então que aprender a viver sem Peléto.

Fábio Andrade fez uma crítica muito bonita sobre Esperando Telê na revista Cinética, por ocasião da exibição do filme na Mostra de Tiradentes de $2010^{11}$. No entanto, ele considerou esse momento em torno de Pelé como um dos "desvios tão brutais" do filme, "que por vezes parecem realmente perdidos dentro de outro filme". Ainda que ele elo-

\footnotetext{
${ }^{10}$ Texto de Michel Laurence, com edição de imagens de Marcos Carvalho. Material da TV Cultura apropriado por Rubens e Tales.

11 "Oitavo dia: das afecções. Esperando Telê, de Rubens Rewald e Tales Ab'Sáber; e Pacific, de Marcelo Pedroso". Disponível em http://www.revistacinetica.com.br/tiradentes10dia8.htm .
} 
gie o que percebe como uma desobediência que marca toda a montagem, sugere algum incômodo com esse momento dedicado a Pelé, como se não fosse necessário ao todo do filme.

Talvez seja justamente o contrário, talvez esse aparente desvio seja extremamente significativo para entendermos o principal propósito do filme. Sem Pelé, até a Copa de 1994, o Brasil nunca mais havia sido campeão mundial. A seleção de 1982 não era inferior às seleções de 1958 e de 1970, que tinham Pelé. Há quem considere a seleção de 1982 inclusive o melhor time que o Brasil já teve. Mas perdeu a Copa.

A partir dessa derrota teve início um processo de mudança no futebol brasileiro, e o Pelé do fora-de-campo, nada perfeito, teve papel ativo nesse processo. De futebol-arte o futebol brasileiro foi reduzido a um futebol-mercadoria. Como disse Tales Ab'Sáber no debate em torno de Esperando Telê que realizamos pelo Grupo História da Experimentação no Cinema e na Crítica, na ECA-USP, em 2015, "não interessava mais ao futebol brasileiro o modo de ser do futebol brasileiro".

E isso se aplicava também às transformações por que passava o cinema brasileiro, no início do chamado "cinema da retomada". Nas palavras do Tales, naquele mesmo debate:

Não interessava mais o modo de ser de um cinema moderno, de um cinema inventivo, experimental, de um cinema que corra riscos, que foi o momento forte do cinema brasileiro. Para mim era muito claro que estava se queimando as potências do cinema brasileiro precocemente, antes de leva-las às ultimas consequências. Já havia todo um discurso técnico de que o cinema tinha que desempenhar as banalidades que vão desaguar no cinema-televisão que está ai ${ }^{12}$.

\footnotetext{
${ }^{12}$ Áudio do debate disponível, na íntegra, na página do Grupo História da Experimentação no Cinema e na Crítica: https://historiadaexperimentacao.wordpress.com/encontros/. Neste debate fui responsável por arriscar uma análise da obra, tendo visto o filme pela primeira vez na ocasião. No áudio é interessante perceber que tudo que escrevo aqui já estava presente nas minhas primeiras impressões/nas minhas intuições de como eu abordaria o
} 
Curiosamente, é na apropriação anárquica de materiais da televisão, sem qualquer preocupação com citação de fontes ou pedidos de autorização, que o filme coloca o cinema brasileiro moderno em movimento novamente. Em meio à predominância de imagens da TV, há sempre a sinalização de algo que acontece por fora, do lado de cá do portão do São Paulo Futebol Clube, que Rubens e Tales nunca conseguem adentrar (a não ser pelas frestas do portão, valendo-se do zoom de sua câmera de vídeo Hi-8).

Os dois têm plena consciência que esses momentos do lado de cá são relevantes. Desde a primeira tentativa de conversar com Telê, ao descer do carro, Rubens orienta Tales, que está atrás da câmera: "Sai comigo!" (ou seja, pede para Tales descer do carro com ele e gravar sua conversa com o porteiro). Gravar a própria equipe de realização de um filme no momento de feitura do filme é um procedimento reflexivo comum em documentário, e a graça de um filme pode estar no modo como essa presença da câmera/da equipe é revelada.

Esperando Telê encanta na medida em que fracassa. Diferentemente do mundo dos esportes, o filme deixa claro que, na arte, o aperfeiçoamento só pode surgir da inadequação. No último diálogo que Rubens e Tales travam dentro de um carro em movimento, já quase no final da obra, Rubens pergunta: "E se chegar janeiro, fevereiro, e a gente não conseguir essa porra dessa entrevista"? Tales responde: "A gente faz o que a gente tiver que fazer. Faz o filme, sem o Telê. Azar o dele”.

Rubens e Tales não podiam controlar os rumos que o futebol estava tomando sem Telê na seleção brasileira, mas assumiram a sua responsabilidade pela direção de um cinema que (re)inventa a partir do que

filme, se fosse um dia escrever sobre ele. A diferença é que essas impressões individuais puderam se beneficiar das falas dos demais presentes, tornando a minha crítica de hoje menos minha, mais coletiva. 
(não) tem. Jean-Claude Bernardet declarou, em um debate sobre o filme no Centro Universitário Maria Antônia, em 2007, ter a certeza de que os realizadores não queriam fazer essa entrevista de verdade:

É interessante a situação fictícia em que os personagens autores do filme, que não querem fazer aquela entrevista, nos convencem, ficcionalmente dentro do documentário, que querem fazê-la, que querem encontrar Telê Santana. Se este desejo fosse realizado é óbvio que o filme não existiria, pelo menos como é, e este desejo encenado é portanto uma ficção de um desejo, encenada ${ }^{13}$.

Apoiada nesta fala de Jean-Claude, entro na minha singela contribuição aos meios e processos audiovisuais, na minha tese propriamente dita. Identifico na postura que Rubens e Tales assumem diante da câmera na sua revelação da consciência da presença da câmera, ou encenação para a câmera, como nota Jean-Claude - uma disposição performática. O que Rubens e Tales fazem é, além de cinema, performance.

Em um primeiro momento, Esperando Telê pode ser lido como um ensaio; uma reflexão sobre o futebol e o cinema brasileiros, em um período de transição, cujos fracassos (mais do futebol que do cinema) são refletidos na forma do filme. Uma das atribuições do ensaio é existir como tentativa, tentativa de aproximação com um tema, algo que ainda não é, pensamento se formando. Rubens e Tales ensaiam entrevistar Telê Santana enquanto o futuro do futebol, do país e do próprio filme são incertos.

Chamo atenção também para a liberdade presente na montagem da obra, que alterna cenas de naturezas muito distintas, sem uma ordem clara (as cenas cotidianas que registram pessoas anônimas jogando bola pelas ruas de São Paulo e do Rio de Janeiro e na praia de Copacabana,

\footnotetext{
${ }^{13}$ A transcrição do registro deste debate não está publicada, mas foi generosamente compartilhada pelos realizadores com o Grupo História da Experimentação no Cinema e na Crítica, do qual faço parte.
} 
por exemplo, poderiam ter sido inseridas antes ou depois dos momentos em que foram inseridas, sem que houvesse grande prejuízo para a construção de sentido ${ }^{14}$ ). No mesmo debate na Maria Antônia, Ismail Xavier falou em "filme que não tem centro" e Marcelo Machado mencionou um "efeito abusado", "de quem vai fazendo o que não pode ser feito, porque neste filme pode" ${ }^{, 15}$. Se tomamos ensaio como anti-gênero $\mathrm{e}$ anti-método, estamos mesmo diante de um filme-ensaio.

Ocorre que, para mim, analisar este filme somente como ensaio talvez não dê conta do que ele guarda de mais charmoso. Seu aspecto original, para mim, está em como se dá a presença de seus realizadores em cena.

Como afirmei anteriormente, são muitas as definições de performance. Além das noções que já mobilizei, na primeira parte da tese, neste momento irei me apoiar essencialmente nas explicações de Renato Cohen e Jorge Glusberg sobre o performer. Cohen qualifica o criador de uma performance como um ator-encenador ${ }^{16}$. Para Glusberg, o performer é, ao mesmo tempo, protagonista e observador de sua própria produção ${ }^{17}$.

\footnotetext{
${ }^{14}$ Eu teria que refletir melhor sobre essa afirmação, dado que em um desses momentos, apenas como exemplo, Rubens e Tales estão dentro do carro falando sobre Collor (a única menção nominal a Collor em todo o filme) e avistam pessoas jogando bola do outro lado da avenida. Eles interrompem a conversa sobre a situação política do país e vão registrar a cena, desviando o foco novamente para o futebol. O que estou tentando dizer é que cada um desses momentos cumpre um papel principalmente em relação à cena imediatamente anterior ou posterior, mas que, pela liberdade improvisada que os caracteriza, talvez pudessem uns substituir os outros sem que houvesse alterações na percepção do filme como um todo.

${ }^{15}$ Da mesma transcrição mencionada anteriormente.

${ }^{16}$ Performance como linguagem. $2^{\mathrm{a}}$ edição. São Paulo: Perspectiva, 2004. p. 98

${ }^{17}$ A arte da performance. São Paulo: Perspectiva, 1987. p. 76
} 
Para a presença de diretores e diretoras no enquadramento de seus filmes se constituir como performance, nos termos aqui propostos, é fundamental a sua presença (ou consciência) atrás da câmera também, simultaneamente. E isso os meninos de Esperando Telê fazem literalmente, ao se alternar ora na frente, ora atrás da câmera, dado que há um revezamento entre quem segura a câmera e quem aparece no quadro; entre quem filma e quem é filmado. Sendo que os dois, ao mesmo tempo, atuam e se auto-observam, independente de quem está na frente e de quem está atrás da câmera. Por isso escolhi este filme como exemplar de minha tese, mas há outros, sobre os quais já escrevi um pouco ou ainda quero escrever um dia:

Abbas Kiarostami e Mohsen Makhmalbaf em Close up (Abbas Kiarostami, 1990) Agnès Varda - Os catadores e eu (2000) e As praias de Agnès (2008)

Andrea Tonacci - Serras da desordem (2006) e Já visto, jamais visto (2013)

Carlos Nader - Carlos Nader (1998)

Chantal Akerman - obras diversas de sua filmografia

David Perlov - O diário (1973)

Eduardo Coutinho - obras diversas de sua filmografia

Glauber Rocha - Barravento $(1962)^{18}$ e Claro (1975)

Jean-Luc Godard - obras diversas de sua filmografia

Jean-Rouch e Edgar Morin - Crônica de um verão (1961)

João Moreira Salles - Santiago (2007)

John Cassavetes - Os maridos (1970)

Joris Ivens - I-film (inacabado)

Lars von Trier em O humilhado (Jesper Jargil, 1998)

Maria Clara Escobar - Os dias com ele (2012)

Mohsen Makhmalbaf - Salve o cinema (1995)

Rogério Sganzerla - Sem essa aranha (1970) ${ }^{19}$

Werner Herzog e Jean-Luc Godard em Quarto 666 (Wim Wenders, 1982)

\footnotetext{
${ }^{18}$ Cena em um terreiro, Glauber gesticulando bastante ao fundo, ordenando "Corta!" para a câmera.

${ }^{19}$ Interessa-me o breve momento em que a equipe do filme se posiciona diante de um espelho.
} 
Wim Wenders e Nicholas Ray em O filme de Nick (Wim Wenders, 1980)

Yvonne Rainer - Vidas dos performers (1972)

Por muito tempo tive dificuldade em elaborar o que amarra os diferentes filmes do meu interesse, pois ainda que todos tenham em comum a presença de seus realizadores diante da câmera, essa presença se dá de maneiras variadas e muito singulares, às vezes até mesmo sem se constituir como uma presença física literal. Eu pensava que o que mais aproximava todos os filmes era a minha relação afetiva com eles. E ainda que essa relação afetiva seja sempre um critério determinante, ao fim percebi que se há um traço comum entre todos os filmes escolhidos não é exatamente a presença dos seus realizadores diante da câmera, mas, fundamentalmente, a sua presença atrás dela. Ou, mais apropriadamente, o jogo que se dá entre essas duas posições, que existem simultaneamente.

Daí a escolha da frase "Estou na frente da câmera mas a minha cabeça está atrás dela", dita por Jean-Luc Godard durante a sua participação no filme Quarto 666 (Wim Wenders, 1982), como título da minha pesquisa. É esse jogo entre estar na frente e atrás da câmera, estar aqui e acolá (lembrando o título de um belo filme de Godard e Anne-Marie Miéville $)^{20}$ que, para mim, caracteriza a performance do diretor ou a performance da diretora.

E para ser performance de fato, não basta um diretor/uma diretora estar na frente e atrás da câmera. A graça está nos modos como essa consciência da presença da câmera ou como esse jogo entre atuar e ser observado/observada é revelado. A reflexividade fílmica que busco qualificar como performance é sintetizada por Jay Ruby nesta passagem:

\footnotetext{
${ }^{20}$ Ici et ailleurs (Jean-Luc Godard e Anne-Marie Miéville, 1975).
} 
Ser reflexivo não é apenas ser autoconsciente (self-aware), mas ser suficientemente autoconsciente (self-aware) para saber que aspectos do self são necessários para revelar, de modo que um público seja capaz de entender tanto o processo empregado como o produto resultante e saber que a revelação em si é proposital, intencional, e não meramente narcisista ou acidental ${ }^{21}$.

Novamente no website naocaber.org será possível encontrar um complemento a esta parte escrita da tese, pois ali estou publicando, pouco a pouco, críticas de mais filmes em que identifico essa reflexividade performática, entre os filmes por mim listados. Adianto breves observações sobre três cineastas cuja presença na própria obra é absolutamente marcante, de modo que, na lista, apontei "obras diversas de sua filmografia”, e não filmes específicos:

\section{Jean-Luc Godard}

Um ator-observador de si mesmo bastante crítico, sempre se comunicando mais através de dúvidas que de afirmações e capaz de nos surpreender com autocríticas severas. No final de Le gai savoir (1969), sua voz over coloca o trabalho inteiro sob suspeita: "Este filme não é o filme que precisa ser feito".

\footnotetext{
21 "To be reflexive is not only to be self-aware, but to be sufficiently selfaware to know what aspects of self are necessary to reveal so that an audience is able to understand both the process employed and the resultant product and to know that the revelation itself is purposive, intentional, and not merely narcissistic or accidentaly revealing". RUBY, Jay. The image mirrored: reflexivity and the documentary film. In: ROSENTHAL, Alan (org.). New challenges for documentary. Berkeley/Los Angeles/Londres: Univ. of California Press, 1988. p. 65-66. Grifo meu.
} 
Na abertura de $J L G / J L G$ (1994), a sombra de Jean-Luc Godard adulto, que manipula uma câmera, é sobreposta a seu retrato de menino. Ouvimos o som de crianças brincando e, aos poucos, uma narração pausada e ofegante de Godard anuncia a sua entrada em cena:

Exercício 174: Autorretrato em dezembro. Escolher o elenco. Começar os ensaios. Resolver problemas relativos à direção. Aperfeiçoar as entradas e saídas. Aprender seu papel de cor. Trabalhar para melhorar sua interpretação. Entrar sob a pele de um personagem. Ter o papel de...

Godard anuncia um espetáculo de si mesmo que, no entanto, ainda é um “ensaio geral”, que poderá ser "um sucesso, um triunfo ou, ao contrário, um fracasso".

A disposição performática, autocrítica e reflexiva de Godard assume também um caráter fortemente anti-institucional; não necessariamente de críticas nominais às instituições, mas na criação de problemas para as mesmas, como ocorreu no processo da exposição "retrospectiva não retrospectiva" de sua obra, que teve sua curadoria, no Centre Georges Pompidou, em $2006^{22}$ (e aqui novamente ele desempenhou um duplo papel, de artista-curador, ou de curador de sua própria obra/de alguém que observa e reflete sobre a própria produção como parte fundamental da obra).

${ }^{22}$ Ver OBRIST, Hans Ulrich. Caminhos da curadoria. Rio de Janeiro: Cobogó, 2014. 


\section{$\underline{\text { Chantal Akerman }}$}

Ao ser convidada para realizar um episódio da série Cinéma, de notre temps, que a cada vez tem um cineasta convidado homenageando outro cineasta, ela teria dito "Alors moi!" (“Então eu!’) para Janine Bazin e André S. Labarthe, produtores. Akerman decidiu homenagear a si mesma e esse não foi exatamente um gesto egocêntrico ou impensado, mas uma performance muito responsável, precisa $^{23}$, que faz todo sentido na sua filmografia. Já no primeiro filme de Akerman, o curta-metragem Saute ma ville (1968), há um pedaço de papel atrás de uma porta que diz: "C’est moi!" (“Sou eu!"). Mesmo se tratando de uma pequena ficção, na qual a personagem principal irá explodir a casa (a cidade) onde vive, a diretora faz questão de deixar claro que é ela mesma quem está em cena, ou de sugerir que é ela mesma quem quer que tudo exploda. Mais que um detalhe, o recado em primeira pessoa dá qualidade performática à sua atuação e prenuncia o gesto auto-referencial que será marcante em quase toda a sua produção.

Entre 1968 (Saute ma ville) e 2006 (Là-bas), Chantal Akerman fez uma série de autorretratos, valendo-se de diferentes recursos de autorrepresentação: La chambre (1972), Je tu il elle (1974), News from home (1977), Les rendez-vous d'Anna (1978), L'homme à la valise (1984), J'ai faim, j'ai froid (1984), Lettre d'une cineaste (1984), Le journal d'une paresseuse (1986), Portrait d'une jeune fille de la fin des années 60 à Bruxelles (1993), Chantal Akerman par Chantal Akerman (1997) e Le jour où (1997). O filme Les années 80 (1983) é uma espécie de making of do processo de realização do musical Golden Eighties (1986); e ali vemos Akerman dirigindo os atores/cantores/dançarinos se divertindo muito com a própria encenação.

\footnotetext{
${ }^{23}$ Lembrando a noção anteriormente proposta, de performance como resposta crítica, como modo/procedimento de "não caber".
} 


\section{Eduardo Coutinho}

Em Jogo de cena (2007) a dimensão performática se dá menos pela presença de Coutinho em cena que pela mistura que ele promove entre mulheres "verdadeiras" e mulheres "atrizes" (todas sendo, ao mesmo tempo, atrizes e verdadeiras). Ainda assim me interessa investigar seu gesto como diretor durante o momento de formação das imagens (durante as entrevistas, em especial nos momentos de conversas dele com as atrizes, nas vezes em que elas representam outra mulher e não elas mesmas) e também em outros filmes de sua produção, especialmente no seu filme póstumo, não finalizado por ele.

A primeira cena de Últimas conversas (2015) é um desabafo de Coutinho para a câmera (com consciência total de que aquele momento era gravado, dizendo "corta!" ao final) e há um momento em que a fumaça do cigarro do realizador, posicionado atrás da câmera, invade o enquadramento/a área onde está posicionada a garota a ser entrevistada, como se a fumaça fosse uma extensão do corpo do diretor ou mesmo seu próprio corpo em cena. Não há como saber se essas cenas estariam no filme se este tivesse sido editado com a supervisão de Coutinho, mas no filme que existe as cenas estão lá e nos contam um pouco do processo e do método de direção do realizador.

Em Santo Forte (1999), interessa-me a cena em que Coutinho mostra o pagamento de cachê a uma entrevistada. Em Peões (2004), interessame escrever a partir da pergunta final que seu entrevistado faz a ele. E assim por diante. Deixo em aberto por ainda não ter elementos suficientes ou mais tempo para escrever, mas também para assumir o que faço aqui como um exercício de crítica, que, para chegar a ser crítica, precisa ser compartilhado. A ideia é instigar o leitor/a leitora da tese a rememorar que momentos, na obra de Coutinho, seriam apropriados ou desafiadores para esta abordagem. Sugestões de filmes/cenas tanto na obra de Coutinho, como de outros filmes para a lista, serão muito bem 
vindas. O que eu não der conta como crítica posso talvez dar conta como curadora - por exemplo realizando uma mostra sob o nome "Estou na frente da câmera mas a minha cabeça está atrás dela" -; como professora, escolhendo excertos dos filmes para mostrar e comentar em aula; ou como editora, convocando mais pessoas a escrever críticas a partir desse desejo de pensar o cinema em relação com a performance.

\title{
Graziela Kunsch
}

Além dos cineastas referenciados estou inserindo a minha própria prática como diretora-performer na história dessa produção. No website naocaber.org preparei uma coleção de registros de palestras minhas nos últimos seis anos, sob o título Efeito-câmera (2016), em que pedi para a câmera de vídeo ser virada para a plateia ou para outras direções, dependendo de cada situação, de modo que não estou enquadrada enquanto minha palestra acontece e só se ouve a minha voz. Esses vídeos foram publicados por diferentes pessoas ou instituições em canais como YouTube, muitas vezes em meio a palestras "normais", quando havia mais palestrantes comigo na mesa. Recorro a Ismail Xavier para explicar o meu gesto/esta obra:

\begin{abstract}
No documentário, o efeito-câmera (olhar e enquadramento que separa um campo visível) é uma instância de teatralidade que acentua o gesto performativo dos que estão sob o olhar da câmera, como acontece com os entrevistados, cientes de que o registro terá dimensão pública. (...) O falar de si só convence se a performance conseguir um efeito de autenticidade, não como ilusão de não encenação, mas como autenticidade produzida na encenação. ${ }^{24}$
\end{abstract}

\footnotetext{
${ }^{24}$ XAVIER, Ismail. A teatralidade como vetor do ensaio fílmico no documentário brasileiro contemporâneo. In: Aniki: Revista Portuguesa da Imagem em Movimento. América do Norte, 1, jan. 2014. Disponível em: http://aim.org.pt/ojs/index.php/revista/article/view/52/19. Acesso em 14/03/2016. Grifos meus.
} 
Entre os demais exemplos da minha performance como diretora que poderão ser vistos no naocaber.org, destaco o filme Pornô (com Stewart Home, 2003); o excerto Reunião na Sehab do arquivo da Vila Itororó (2006); e os excertos das conversas do Projeto Mutirão (desde 2005).

\section{Projeto Mutirão}

Desde 2003 acompanho uma série de lutas coletivas de transformação social e espacial com uma câmera de vídeo e também coleto gravações brutas feitas por outras pessoas. Exemplos: pessoas abrindo a porta traseira de um ônibus para usar o transporte coletivo sem pagar, sem passar pela catraca; ocupando terras ou prédios abandonados e transformado radicalmente o espaço, no cotidiano; pintando ciclofaixas no asfalto (antes de existirem as ciclovias feitas pela prefeitura, no caso de São Paulo); plantando agroflorestas; mudando as posições das carteiras em uma sala de aula/escola etc.

São muitas horas registradas, que poderiam render um ou mais documentários. Entendendo essas lutas como um processo interminável, não quis delimitar um fim para esse trabalho. As pessoas que lutam por mudanças raras vezes conseguem viver aquilo que sua luta conquista, quando conquista algo. Assim, achei mais apropriado assumir o que venho fazendo como uma prática, uma ação que tem continuidade e que não é direcionada para um produto.

Cada vídeo do projeto é formado por um único plano cinematográfico, sem edição. Chamo esses planos de "excertos" 25 . Cada excerto pode ser

\footnotetext{
${ }^{25}$ Não uso a expressão "plano-sequência" para nomear estes planos, mesmo quando longos, porque ao criar esta expressão André Bazin estava se referindo a planos de filmes que cumpriam a função dramática da seqüência de planos no esquema de decupagem clássica. Uma análise do meu trabalho exige outro vocabulário; de modo a explicitar que o que faço é tão somente extrair um trecho de um material bruto. "Excerto", no Moderno Dicionário Michaelis, significa: (adj) tirado, extraído. (sm) trecho.
} 
entendido como uma pequena peça, parte de um processo maior, carente de articulação. De modo que essa articulação seja coletiva - no sentido de não ser editada por mim -, há mais de dez anos levo o arquivo com esses excertos para contextos/públicos os mais diferentes: pode ser uma escola de crianças, um assentamento rural, uma ocupação de sem-teto, um festival de cinema, uma universidade, uma aldeia indígena, um museu de arte, na rua etc. ${ }^{26}$

A cada contexto/público específico escolho alguns excertos para mostrar e começar uma conversa. Conforme o diálogo avança, escolho novos excertos e assim por diante. Todas as conversas do projeto são registradas em vídeo e excertos reflexivos dos encontros incorporados ao arquivo e, consequentemente, nas próximas conversas.

Pode-se dizer que eu me tornei uma personagem do trabalho, desempenhando diferentes papéis - ora é a Graziela artista, ora a ativista, ora a professora quem fala.

\footnotetext{
${ }^{26}$ Além de realizar o projeto em diversos contextos políticos - por exemplo junto a uma comunidade de Bogotá que há mais de dez anos resiste a um processo de gentrificação; com crianças da Politeia Educação Democrática; durante trabalho de base do Movimento Passe Livre; na primeira comuna urbana do MST; nas escolas ocupadas em São Paulo no final de 2015; entre outros tantos lugares de luta, participei com esta obra de um workshop da Documenta 12 (The position of the speaker, Kassel - Alemanha, 2007, apoio Ministério da Cultura) e da exposição $29^{a}$ Bienal de São Paulo (2010). Desde então, realizei o projeto em diversas exposições/instituições culturais: The Grand Domestic Revolution (Casco, Utrecht - Holanda, 2010 e 2011); Conversas (Museu da Gravura de Curitiba, 2011); todos os três capítulos da exposição All that fits: the aesthetis of journalism - 1. The speaker 2. The Image 3. The militant (QUAD, Derby - Inglaterra, 2011, apoio Ministério das Relações Exteriores); Blind Field (Krannert Art Museum, Urbana - Estados Unidos, 2013); O abrigo e o terreno (MAR - Museu de Arte do Rio, Rio de Janeiro, 2013); Campo Neutral (Museu da Gravura de Curitiba, 2013); Escavar o futuro (Palácio das Artes, Belo Horizonte, 2013); O público de fora (Centro Cultural São Paulo, 2014); Revolution without movement (Tranzit e HIT, Bratislava - Eslováquia, 2014); Vila Itororó Canteiro Aberto (São Paulo, 2015); Educação como matéria prima (MAM São Paulo, 2016); e Provocar urbanos (SESC Vila Mariana, São Paulo, 2016). Estas duas últimas seguirão em cartaz quando da defesa da presente tese e quem puder visita-las verá que proponho soluções formais diferentes em cada contexto.
} 
No final da minha dissertação de mestrado, no capítulo intitulado "Prática reflexiva", eu informei que, no dia da defesa, cogitava ler um texto sobre o Projeto Mutirão, referenciando a mim mesma na terceira pessoa. E continuava:

Mas será possível falar de Graziela Kunsch na terceira pessoa? Como, estando tão perto? Mas paradoxalmente tão longe se pretendo falar de uma personagem construída, de uma artista. Olhar sempre de perto, olhar todos os dias. Parece uma receita certa para se conhecer algo ou alguém. Mas também parece a forma mais difícil. São precisos registros: palavras e imagens, que dizem das coisas não como elas são ou se organizam agora, mas como foram e sugeriam algum sentido em outro momento. Nesse lapso, nesse reconhecimento sem reconhecer, nessa identificação tanto da permanência quanto da mudança, ou mesmo na dúvida daquilo que permaneceu de fato e aquilo que efetivamente mudou, nessa experiência que se pode reviver no tempo, mas não de fato. Seria a experiência aquela única, registrada, mas definitivamente passada no tempo, ou aquela que se produz nessa volta ao registro, possivelmente delineando um sentido outro, sem ser, no entanto, definitivo? É isso que penso ao ver alguns desses vídeos (inseridos dentro de um vídeo maior, de uma hora, que registra uma aula) e ler esse texto de Graziela Kunsch em processo, inacabado, aberto no sentido mais verdadeiro (continuará assim quando estiver terminado, entregue, defendido?) (...)

A recusa em fechar a forma, o voltar-se constantemente para ela, questioná-la, incorporar a discussão, a apresentação, a crítica, o comentário alheio, tudo isso. A discussão sobre um excerto pode ser um excerto ${ }^{27}$.

${ }^{27}$ Projeto Mutirão. ECA-USP, 2008. 
Um dos objetivos do Projeto Mutirão é refletir sobre o papel de indivíduos - aí incluído o artista individual - em processos históricos coletivos. Nos últimos anos, vídeo-ativistas/artistas que participaram de conversas compreenderam tão bem a proposta que começaram a tocar suas próprias conversas do projeto; usando seus próprios vídeos (excertos), registrando as conversas e incorporando esses registros (e suas aparições como personagens) na forma de novos excertos do arquivo.

Hoje estou começando uma nova experimentação, com um grupo de mulheres de diferentes idades e contextos/experiências (uma atriz/dançarina, uma mutirante da Comuna Urbana Dom Hélder Câmara, uma estudante da escola ocupada Mazé, entre outras). O processo está ainda muito no início, mas a ideia será gravá-las, uma por vez, assumindo meu próprio papel na condução de uma sessão do projeto. Mais exatamente, apropriando-se do meu papel, da maneira delas, a partir da própria vivência e compreensão que elas tiverem do projeto, e de suas próprias experiências de vida. Apenas será importante que as conversas sejam reais (aí cabendo toda desconfiança de quem me lê) e que as mulheres assumam o Projeto Mutirão como uma proposição de sua autoria. E que eu esteja presente, como diretora, na frente e atrás da câmera. Imagino que no futuro terei tanto excertos de falas delas sozinhas, na condição de propositoras, como excertos em que fique explícita a minha direção e elas como atrizes (lembrando que esses planos não serão montados em sequência, mas ficarão isolados, no arquivo, podendo ou não ser aproximados em futuras conversas).

Aqui estou chamando atenção para a minha própria performance na obra, mas é importante deixar claro que, nas conversas, não sou apenas eu quem fala ou quem controla o discurso; ainda que, posteriormente, eu seja responsável por selecionar os trechos das conversas que irão para o arquivo (o que poderá mudar um dia). 
Uma vez que as falas de participantes das conversas podem ser vistas nos vídeos, escolhi trazer para cá uma crítica escrita, a mais dedicada que recebi sobre o projeto. Trata-se de um artigo de Irene Small na revista Artforum, em edição inspirada por junho de 2013 no Brasil ${ }^{28}$ :

(...) How might we think about the circulation and occupation of images together with those of bodies in space? A video from artist Graziela Kunsch's ongoing work Projeto Mutirão, begun in 2003, gives one indication. The piece documents an intervention in which transportation activists wrest open the back doors of a public bus in São Paulo, allowing a stream of riders to enter without paying in front. The clip itself is brief - only thirty seconds - and was culled from extensive footage that Kunsch shot as part of her work with housing, free-transport, and independent-media movements. That such raw footage appears in Projeto Mutirão in the form of long takes is key, and Kunsch is explicit in her debt to Bazin. But as Pasolini recognized, the long take inevitably entails the cut, which transforms the present tense of reality - in all of its excess and ambiguity - into a past that can accrue signification. From her raw footage, for example, Kunsch isolates moments that embody the concept of mutirão: a term that refers to acts of participatory mutual aid, often temporary in nature. Sometimes these extracts are climactic, like the opening of the bus doors or the burning of a turnstile. But just as often they are oblique, ephemeral, and indexed to moments of observation: the tacking of a tarp onto a jury-rigged shelter; a cleaning collectively organized in a squatter camp; a pair of young boys transforming a construction site into a makeshift playing field. All represent openings and hiatuses in which social orders are rethought.

These extracts form a mobile, open-ended archive that Kunsch uses as a catalyst for dialogues in schools, art exhibitions, workshops, community meetings, and public forums. She also includes footage shared by other activists, as well as clips from prior conversations. The archive thus opens out onto multiplicitous repositories of images and actions, each with its own viewpoint, modes of visual apprehension, and political aims. Yet the archive functions as a selfreflexive device as well, revealing the work's highly mediated nature, the degree to which Kunsch becomes a protagonist herself. Because Projeto Mutirão is realized only by means of discussion and debate, however, Kunsch's navigation through this video material is contingent on the social process of its reception within a given time and place. And because each encounter is recorded in turn, the project has a feedback mechanism that incorporates both critique and historicity.

${ }^{28}$ SMALL, Irene. Live Streaming: on Documentary Strategies in Brazilian Art and Activism. In: Artforum, edição impressa de maio de 2014. Grifos meus. Desculpo-me por não ter traduzido para o português. 
In this, Projeto Mutirão diverges from the instantaneity of both surveillance and documentary counterinformation in favor of multiple temporalities that unfold unevenly in real time. Of course, as much might be said of a Facebook feed. But by insisting on the co-presence of archival moving images with talking, thinking, feeling bodies, Kunsch's project models - in terms of concrete experience - the ways in which we catalyze action by traveling between screens and space.

The filmmaker and writer Hito Steyerl recently asked whether the Internet was dead. Not because it has been superseded, but because it is "all over," which is to say that it has infiltrated the epistemologies and operations of the offscreen world. The negative implications are too copious to catalogue. But Steyerl hazards a further question: "If images can be shared and circulated, why can't everything else be too?" What would it be like, in other words, if online behaviors migrated off-line - toward the production of a lived commons? What if the virtual circulation of images really impacted the circulation of bodies in space? The Brazilian protests proved, once again, that this can happen. Kunsch's project, meanwhile, helps us comprehend the interval between these two types of circulation as a shared project of mutirão. 


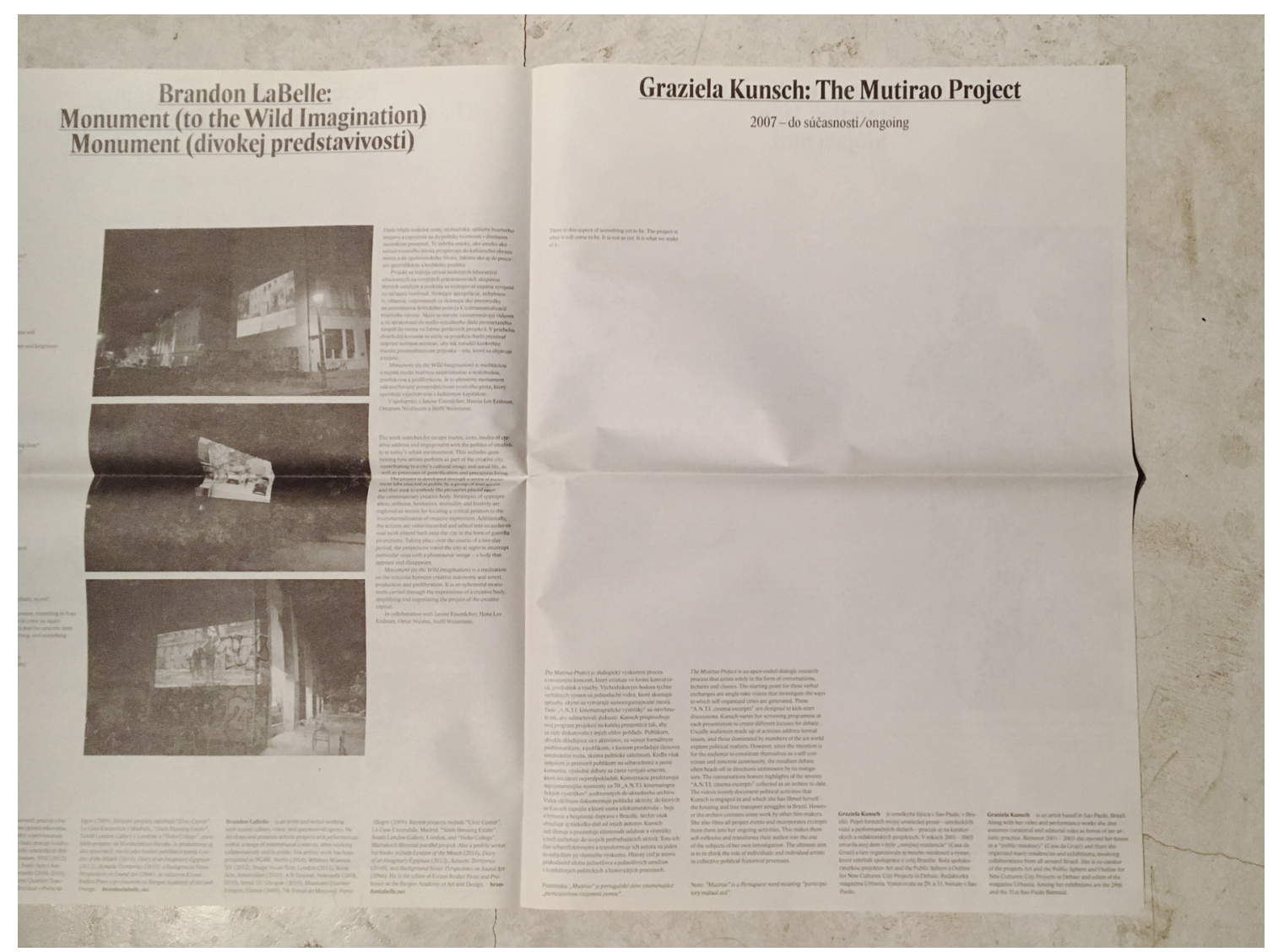

Lado direito da imagem: página dedicada ao Projeto Mutirão no jornal/catálogo da exposição Revolution without movement (Tranzit e HIT, Bratislava, 2014). No alto, o texto pequenino diz:

"Há esse aspecto de algo que ainda não é. O projeto será o que nós fizermos dele". 
A performance da crítica

Eu pensava em estruturar uma fala para apresentar meus trabalhos da melhor forma possivel para vocês mas, ao invés de o MAC me encontrar, eu acabei optando por tentar encontrar o MAC.

Em uma conversa preparatória da atividade de hoje, a Luiza Proença, do grupo que está organizando esses encontros junto ao Tadeu Chiarelli, me disse que uma pergunta que ela tem feito a quase todos os artistas que vêm aqui é: "O que você espera do MAC?"

Coincidentemente, antes de ouvir essa pergunta da Luiza, eu vinha pensando em doar todos os meus trabalhos de 1999 até hoje, incluindo algumas correspondências pessoais, a um museu público. Todos os meus trabalhos estão muito mal guardados, em minha casa, muitas coisas já se perderam... e eu só conseguia pensar no MAC. Mesmo sem saber nada sobre o estado atual do MAC, o meu desejo era, de alguma forma, estar perto da história do MAC. O MAC do Parque do Ibirapuera. Dialogar com aqueles artistas que, nos anos 1970, fizeram coisas incriveis junto ao museu.

Eu venho tentando fazer esse diálogo já há algum tempo. Em 2007, em função de uma pesquisa para o curador alemão Heinz Schutz, e seguindo orientações de Mario Ramiro e Maria Olimpia Vassão, do Centro Cultural São Paulo, pude conhecer, entre outros, a Lydia Okumura, o Genilson Soares e o Francisco Iñarra. Este último - digo isso com muita tristeza - já não está entre nós. Digo com tristeza mas também com alegria, pois tive a sorte de conhecê-lo, de conhecer o seu trabalho e de compartilhar um pouco esse trabalho com mais pessoas durante a 
exposição Não há nada para ver, quando Genilson e Francisco apresentaram seus trabalhos em uma conversa que chamamos de "Apropriação e transformação do museu”.

Retomando o pensamento, o foco da exposição de Heinz Schutz, chamada Performing the city, era reunir performances de rua de aproximadamente 16 cidades, São Paulo uma delas, nos anos 1960 e 70. Uma vez iniciada a pesquisa, percebi que duas inclusões seriam fundamentais: primeiro, prolongar um pouco o período estudado até o começo dos anos 80, quando ocorreram algumas das ações de grupos paulistanos como o 3NÓS3 e o Viajou sem passaporte, que iniciaram sua atuação no final dos anos 70. Segundo, era necessário incluir nessas "ações de rua" as ações que aconteceram dentro do MAC sob a direção de Walter Zanini.

Ou não exatamente dentro. Em 1971, a Equipe 3, formada por Lydia, Genilson e Francisco, instalou na rampa do MAC Ibirapuera três painéis de madeira, um painel a cada curva da rampa. Esses painéis tinham uma pintura de paisagem que camuflava portas, portas escondidas que dificultavam a entrada das pessoas no museu. O primeiro painel tinha a paisagem completa, o segundo parte dessa paisagem e o terceiro, já na entrada do museu, somente a terra e o céu, exigindo ou revelando um apuro na percepção do espectador conforme este subia as rampas e convidando, ao mesmo tempo, esse espectador a ver além - o que é próprio da arte - e a perceber limites - o que talvez seja próprio do тиseu.

Ou seria uma tentativa de provocar os espectadores - aí incluídos todos os artistas que frequentavam o MAC - a romper os limites do museu?

Vale lembrar a primeira “artelação” realizada por Genilson e Francisco em 1975: durante uma exposição do acervo do MAC, eles se 
apropriaram de uma das pedras do artista Shihiro Shimotani, que tinha a inscrição "Event" ["Evento”]. Eles levaram essa pedra para passear pelo Parque do Ibirapuera (onde está o prédio do museu) e pelas ruas próximas ao parque. Colocaram a pedra em contato com a natureza, com o lixo urbano e essas ações foram documentadas em fotografias. Ao devolverem a pedra ao museu mostraram essas fotos para o Zanini.

O diretor e a dupla tiveram uma longa discussão - aqui [no telão] transcrita e reproduzida -, sobre os "valores das obras de arte", da não hierarquia entre as diferentes obras. Zanini dizia que não era por se tratar de uma pedra que poderia sair passeando por aí; que a pedra era tão obra de arte como uma pintura do acervo... 


\begin{tabular}{|c|}
\hline 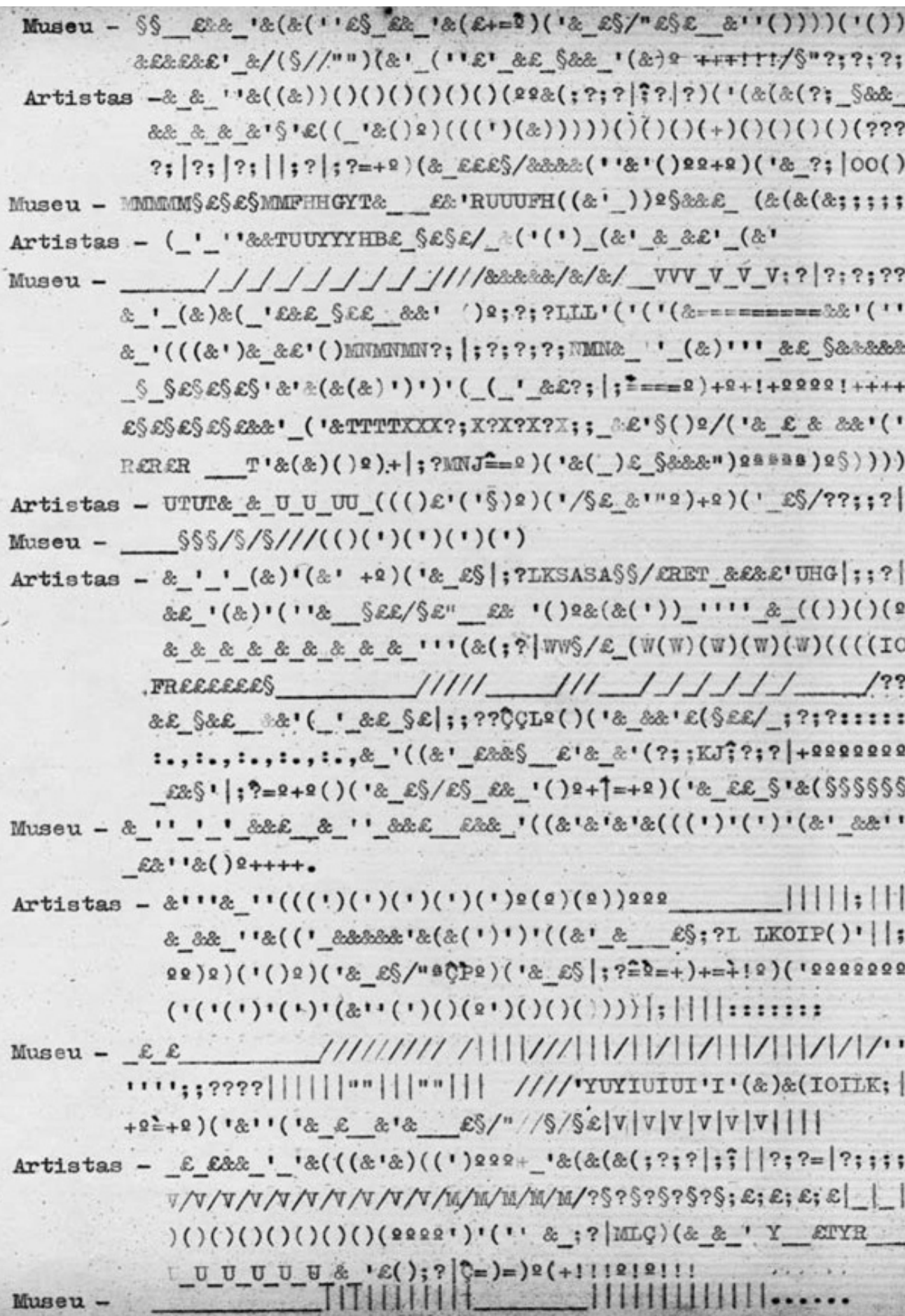 \\
\hline
\end{tabular}

Página integrante da documentação fotográfica da obra Evento com a pedra event, de Genilson Soares e Francisco Iñarra (Arte/Ação), 1975 
Após essa discussão a dupla se apropriou da pintura Cavalos à beira mar, de Giorgio de Chirico, e promoveu o encontro da pedra com o quadro, na área externa do museu. Uma fotografia documenta a pedra ao lado do quadro, sobre a grama do Parque do Ibirapuera.

Eu poderia aqui contar uma série de histórias incríveis que ouvi desses e de outros artistas, mas imagino que alguns de vocês já conheçam bem tudo isso e me pergunto se esse é meu papel. Não sou exatamente uma pesquisadora, pesquisa exige muito tempo e a maior parte do meu tempo é tomada pelos meus próprios trabalhos como artista - que por sua vez também exigem estudos -, pela militância junto ao coletivo da Usina e a movimentos sociais - não separada da minha prática como artista - e pelos meus alunos.

Além disso, sei que existem pesquisas já publicadas - ainda que eu não as tenha lido ainda -, como uma dissertação de mestrado da Dária Jaremtchuk, sobre as exposições Jovem Arte Contemporânea - as JACs e o primeiro capítulo da tese da Magali Sehn, recentemente concluída (2010). Temos também o livro Poéticas do Processo e uma série de textos da Cristina Freire, de quem ouvi ou li pela primeira vez sobre as propostas tocadas e acolhidas pelo Zanini no MAC.

Ocorre que ontem, ao conhecer Donato Ferrari pela primeira vez - fui atrás dele a partir daquele desejo que mencionei no começo da fala, de encontrar o MAC ao invés de o MAC me encontrar -; retomando, na casa do Donato, fiquei chocada ao constatar que suas obras ou ao menos boa parte de suas obras e correspondências pessoais não estão no acervo do MAC, segundo informações dele. Estão no MAC todos os catálogos desenhados por ele - aliás o catálogo da V JAC é a peça de design mais bonita que eu já vi na minha vida, além de ser muito legal, na crítica bem humorada que faz ao júri. É esse material gráfico que leva à dissolução - ou de certa forma anuncia a dissolução - do júri na 
próxima JAC, a VI JAC. Mas, antes de falar da VI JAC, eu queria entender por que as obras do Donato - desde gravuras lindíssimas até documentações de ações que ele realizou no MAC e na Bienal não estão ainda conservadas em um museu. Vejam bem: eu não estou certa se, neste momento, essas obras precisam estar em um museu. Duas gravuras que vi estão muito bem dispostas na parede de sua casa, junto de outras obras suas e de Regina Silveira, entre alguns outros artistas de enorme importância na história da arte brasileira. Essas obras estão, sem dúvida, em um excelente contexto, um contexto afetivo. Os catálogos e outros impressos que fez junto ao MAC nos anos 70 estão organizados em plásticos individuais, em uma pasta verde, do mesmo modo que eu venho me esforçando para guardar as coisinhas que fiz e venho fazendo com amigos nos últimos anos. Mas toda essa documentação é "falha", nas palavras do próprio Donato.

O que esperar do MAC?

Desconheço se já houve negociações entre o museu e o artista (no caso, refiro-me ao Donato), mas de que novos modos, nesse novo momento do MAC, podem se dar as negociações entre museu e artistas? Como não reduzir esta relação a doação, aquisição, conservação e apresentação de obra?

Creio que entre as pesquisadoras da instituição e alguns artistas já existe uma relação forte - o caso de Cristina Freire e Paulo Bruscky é notável -, mas pelo pouco que sei essa relação se dá principalmente a partir de obras já presentes na coleção. A exposição atual MAC em obras aponta caminhos muito interessantes, mas eu teria gostado de ver a sala mais movimentada nas vezes em que estive lá. Não tive a sorte de ver o pessoal responsável pelo restauro das obras, entre outros, trabalhando ali em nenhuma das vezes que visitei a exposição, de modo 
que o que mais vi foram os seguranças. Sei que havia sim pessoas trabalhando ali, que a exposição tem toda uma dinâmica progressiva; estou apenas dizendo que teria gostado, talvez, de ver isso acontecendo com mais intensidade, durante mais vezes na semana.

Mencionei, no início da fala, a vontade de doar toda a minha obra ao MAC. O que não falei é que - caso a equipe do museu se interesse pelo meu trabalho, é claro - é que essa doação seria, na verdade, uma troca. Tenho interesse em trabalhar em colaboração com toda a equipe do museu no processo de preparação dos meus trabalhos para um acervo público. Isso inclui desde ações técnicas como recuperar e digitalizar fitas VHS até trabalhos que, para existir, precisariam ser realizados e permanentemente atualizados pela equipe educativa da instituição. Há também uma série de documentos dispersos que precisariam ser reunidos, como as correspondências entre uma série de coletivos de artistas brasileiros do começo dos anos 2000, depoimentos orais desses mesmos coletivos que fizeram residências em minha casa que precisariam ser coletados, uma porção de registros em vídeo carentes de organização... Cuidar sozinha dos meus próprios processos é muito difícil, como foi e é difícil para o Donato. De que modo o museu pode nos amparar, nos ajudar, tomar decisões junto com a gente?

Como todos sabemos, a função de um museu não é, ou não deveria ser, somente domesticar ou preservar um trabalho... É disponibilizar esse trabalho para muitas pessoas e abri-lo à reflexão... Mas como lidar com obras que não geram objeto algum? Por exemplo, obras atuais que assumem uma forma dialógica - de diálogo -, que não podem ser reduzidas a registros em vídeo, pois são da ordem da experiência?

Como mostrar, no acervo do MAC, o Projeto Matéria, que o Jorge Menna Barreto realizou no Centro Cultural São Paulo em 2004, transformando o espaço expositivo em uma sala de aula? Com fotografias e 
descrições textuais? O programa impresso do curso? Relatos dos participantes? O texto da artista Carla Zaccagnini, então do grupo de críticos do CCSP, que o Jorge impediu de ser publicado junto ao folder da exposição? Sim, pode ser, são documentos históricos relevantes. Mas como manter a atualidade crítica daquela proposição? Em outras palavras, como reinventar o próprio Projeto Matéria, como ele pode seguir existindo? Talvez como uma ação permanente do projeto educativo da instituição? Transformando uma parte do museu em sala de aula? Que espécie de saula de aula? A cada vez, um artista diferente ser chamado para programar e mediar um curso? Talvez, eu não sei, não tenho respostas, e por isso é tão importante que aconteça essa relação franca entre o museu e os artistas, para pensarem juntos, se fortalecerem mutuamente.

Essa relação franca foi muito bem descrita pelo Zanini em 1973, no texto em que ele anuncia o que seria a sétima JAC como uma atividade contínua, não mais pontual/anual, mas uma programação constante. Ele diz assim: "O momento parece oportuno para um breve tratamento da questão das relações entre o museu e o artista. Tradicionalmente considerado pelas entidades museológicas como uma ave da qual apenas os ovos interessam, devemos nos aperceber que de seu vôo podem vir proveitos que contribuam para a forma organizativa de algumas de suas atividades". E, não por acaso, ele amarra seu pensamento citando uma fala do Donato: "O artista deve intervir nos problemas da estruturação do museu”.

No meu esforço de conhecer a história do MAC devo dizer que o que mais me marcou foi a enorme generosidade praticada por diferentes agentes atuantes no museu. A VI JAC, considerada por mim a exposição de arte mais especial da nossa história, ao lado da Do corpo à terra, ambas ocorridas em plena ditadura, foi marcada por extrema generosidade. 
Aos que não conhecem a história da VI JAC, ou JAC 72, tratou-se de uma proposição do Donato Ferrari ao museu, com a colaboração de Raphael Buongermino Netto. O júri de seleção foi eliminado, os artistas inscreveram seus projetos, e foi realizado um grande sorteio que lotou o auditório do MAC Ibirapuera. Neste sorteio cada artista sorteado para participar da VI JAC recebeu o número de um lote. Esses lotes haviam sido desenhados, por sugestão de Donato Ferrari, em colaboração com um grupo de estudantes da FAAP. Havia uma planta baixa mostrando a localização dos lotes tanto no cartaz que anunciava a exposição como riscada, com giz, no espaço expositivo. Não eram lotes quadrados, tinham formas mais orgânicas e havia poucos lotes com paredes. Aproximadamente 80 lotes no total. O artista Gabriel Borba não foi sorteado e a crítica Rhada Abramo, fã de seu trabalho e revoltada com a sua não participação, comprou do artista Cícero Gustavo da Silva, por 200 cruzeiros, seu lote; e o concedeu ao Gabriel para ele desenvolver ali o trabalho que bem entendesse. A Equipe 3, referenciada logo no começo da minha fala, formada pela Lydia, o Genilson e o Francisco, realizou o projeto Incluir os excluídos, executando obras de seis artistas internacionais que não chegaram a ser sorteados. Segundo o Donato, só não participou quem não quis, pois os artistas foram se ajeitando e compartilhando seus lotes dos mais diferentes modos.

Assim, temos inicialmente a generosidade de Zanini que tanto estimulou o Donato a fazer propostas para o museu para além do seu trabalho como designer, e que acolheu essa proposta. Donato que compartilha a responsabilidade sobre o projeto gráfico com um grupo de alunos. Temos, depois, um sorteio provavelmente muito menos excludente/com resultado mais diversificado do que seria a seleção realizada por um júri. A generosidade de Rhada Abramo com Gabriel Borba. Da Equipe 3, incluindo os excluídos. 
Na assembléia final da JAC 72, novamente com um auditório lotado, desta vez com pessoas sentadas até mesmo no chão do palco, a comissão de premiação se viu obrigada a se auto-dissolver e os artistas decidiram, coletivamente, usar a verba dos prêmios para realizar um catálogo mais completo da exposição. A capa desse catálogo, novamente um trabalho genial de Donato Ferrari, se aproveita da foto de um artista que ficou durante toda a assembléia sentado de costas ao fundo do palco com uma camiseta com a inscrição "Ou”. Inserindo essa imagem entre o nome da exposição e o nome do museu, a capa diz assim: "Jovem Arte Contemporânea OU Museu de Arte Contemporânea".

O que eu espero do MAC gera uma outra pergunta: o que o MAC espera do MAC? Qual a obrigação histórica do MAC?

Naquele mesmo texto de 73 Zanini afirmou, corretamente, que a VI JAC era "um acontecimento irreproduzivel". Mas o que aprendemos dessa experiência? O que ainda precisamos aprender? Colocar em prática?

O MAC cresceu, profissionalizou-se, em breve terá um prédio novo. Imagino que o grau de profissionalização ainda não seja ideal e que isso deve sim ser buscado, até mesmo para uma melhor conservação e exposição das obras. Mas qual o papel do MAC? O que leva uma artista como eu, que nunca trabalhou com uma galeria, com uma prática frequentemente associada aos anos 60 e 70 por críticos, a escolher o MAC para cuidar dos meus trabalhos? Qual MAC estou buscando? Já não pode ser o MAC dos anos 70, mas também não precisa ser o MAC atual. Interessa-me um MAC em transição.

Esta série de encontros e a exposição MAC em obras me dão esperança e agradeço muito pela oportunidade de participar deste processo. No entanto, devo dizer que, em alguns registros em vídeo das palestras que 
pude ver no website do museu, fiquei com a impressão de que a ênfase ainda era nas obras dos artistas e menos nas suas contribuições ao museu. Nesses registros, salvo engano meu, pouco se escuta a voz da platéia. E por esses dois motivos hoje acabei optando por não apresentar nenhum trabalho meu e por pedir para a câmera de vídeo da transmissão ao vivo ser virada para vocês.

Existe um texto da Cristina Freire que vez ou outra eu mobilizo; ela diz assim:

É nesse momento que se dá a determinante virada do objeto para o evento que torna as poéticas processuais e conceituais do período tão seminais para a arte contemporânea. A propósito, basta observar a importância que o registro de gestos de artistas, nos mais diferentes meios tecnológicos, ocupa, atualmente, nas exposições de arte contemporânea.

Uma ruptura na lógica aceita e por todos compartilhada do que seja obra de arte é a freqüente ambigüidade e indiferenciação entre documento e obra. Muitos desses projetos fundamentais para os anos $70 \mathrm{fo}-$ ram ações e situações efêmeras, que só existem hoje como registros. A fotografia, os filmes Super-8 e $16 \mathrm{~mm}$ e, posteriormente, o vídeo ocupam aqui lugar privilegiado. Há certa intenção de permanência de algo que definitivamente escapa. Essa presença ausente é o que caracteriza a produção dos anos $70^{29}$.

Do mesmo modo, está ausente-presente aqui a Luiza Proença, que fez a pergunta geradora de toda a minha fala; o Gabriel Borba, que pude finalmente conhecer e teve algumas de suas opiniões sobre o MAC aqui incorporadas ${ }^{30}$; a Marisa Flórido Cesar, que também teve uma fala sua apropriada; o Daniel, meu companheiro, que digitou para mim as citações aqui lidas de modo que eu terminasse esse texto a tempo de vir até a USP; e a minha mãe, que quando eu tinha aproximadamente 9 anos atendeu ao meu pedido de estudar desenho e me inscreveu em um curso no MAC Ibirapuera. Tenho na memória uma aula bastante livre,

${ }^{29}$ FREIRE, Cristina. Poéticas do processo: arte conceitual no museu. São Paulo: Editora Iluminuras, 1999. Grifos meus.

${ }^{30}$ Gabriel não poderia estar de corpo presente, mas ao final conseguiu ir. 
em meio a pessoas bem mais velhas do que eu, que tornou possível que eu pudesse respirar um pouco aquele ambiente, esta história.

A essas pessoas e a vocês, presentes-presentes, agradeço especialmente.

Graziela Kunsch

$M A C-U S P$

16 de agosto de $2011^{31}$

${ }^{31}$ Página sobre a atividade: mac.usp.br/mac/conteudo/cursoseventos/mac encontra/2011_2/kunsch.asp Registro em vídeo (recomendo ver ao menos o começo, com a câmera já virada para a plateia): iptv.usp.br/portal/video.action?idItem $=10612$ Último acesso em 18/03/2016. 
De: Margarida M. Krohling Kunsch

Data: 17 de agosto de 2011 08:21:56 BRT

Para: grazi, Waldemar L. Kunsch, Adriana Kunsch, Clarice Kunsch

Assunto: RES: texto do MAC

Grazi,

Parabéns! Lindo seu texto.

Quem poderia imaginar que depois de tantos anos 23 você iria voltar ao MAC como artista.

Beijos, Mamãe

De: Pablo Ortellado

Data: 17 de agosto de 2011 18:10:30 BRT

Para: grazi

Assunto: Re: texto do MAC

Lindo texto, Grazi. Não esperava menos de você.

Infelizmente não pude ir - dia de ficar com o Pedro.

Beijo

De: Marisa Flórido Cesar

Data: 17 de agosto de 2011 13:44:58 BRT

Para: grazi

Assunto: Re:

e aí grazi, como foi lá? 
De: Jorge Menna Barreto

Data: 18 de agosto de 2011 09:55:52 BRT

Para: grazi

Assunto: Re: texto lido no MAC

querida grazi, fiquei emocionado lendo o seu texto! lindo e muito pertinente! arrasou! a forma como você convoca o museu é incrível, convidando-os a se responsabilizarem também ;-) a imagem do telão é linda também! puxa, grazuka, ontem estive com o vitor aqui em porto alegre, e ele me contou do trabalho dele. dai agora leio o seu email. é tão incrível ver os meus colegas de geração amadurecendo, crescendo, com uma produção cada vez mais consistente! fico emocionado, sabia, de perceber o movimento de vocês!

aliás, a boa notícia é que vou montar o café educativo no panorama. acho que vai ficar bem legal!

beijocas, querida, e obrigado por compartilhar o lindo e inspirador texto!

$j$.

De: Genilson Soares

Data: 18 de agosto de 2011 12:07:40 BRT

Para: grazi

Assunto: Re: oi genilson!!!

Querida Grazi,

Que bela surpresa!... Fiquei emocionado e extremamente agradecido com a sua lembrança, ao incluir em sua palestra, referências sobre os nossos trabalhos, e também, sobre o nosso querido Chico, que nos deixou tão prematuramente.

Queria dizer que recebi o envio/convite do MAC sobre a sua palestra, mas eu não pude ir, porque naqueles dias, eu estava fora de São Paulo, incluindo a noite de sua palestra. Mas, imagino que tenha sido extre- 
mamente gratificante para você, poder estar nesse museu de queridissima memória, ser o foco e estar falando a uma audiência tão seleta, sobre aquilo que poderá ser o MAC, para os anos que virão. Todos nós temos essa esperança (que não quer calar) de que o museu volte a ser uma referência, um fulcro das manifestações experimentais nas artes contemporâneas para os dias futuros, assim como experimentou ser nos finais dos sessenta, e gloriosos anos setenta. Eu também sou muito gratificado, e sinto um orgulho danado, de ter participado um pouquinho das manifestações culturais naquele espaço, ao longo daquelas décadas. Esperamos que com essa imponente nova sede, o museu volte a ter uma atividade dinâmica, e muito viva, como foi no período Zanini. Não se trata de tentar repetir o que foram aqueles dias turbulentos, de vanguarda extrema, mas, ao mesmo tempo, de procedimentos ingenuamente amadores (não havia o feeling, o insight, da necessidade de uma documentação mais ativa, sobre as diversas manifestações acontecidas naquele periodo... talvez, porque estivéssemos todos ao mesmo tempo, “descobrindo o registro”, essa nova inserção e necessidade, que aos poucos, foram agregadas aos nossos trabalhos). Esperamos que o museu (todos os museus) voltem a abrir as suas portas aos artistas, e que todos possam circular livremente, sem seguranças fungando negativas nos ouvidos, com seus "radinhos na escuta", e que todos possam trabalhar em cooperação plena, como foi possível naquele breve período dos 70, com as participações do Donato, do Rafael, do Tomoshige, do Mario Ishikawa \& Guta, do Sparaphan (aquele da camiseta do "ou”), do Gabi, da Anésia, e de tantos outros, que dedicaram uma boa parte de suas vidas, a concretizar aquele sonho, sob a batuta desse grande maestro, que foi o Zanini, na direção do museu.

Queria dizer pra você que no momento estou empenhado na produção de uma exposição para a segunda quinzena do mês de outubro, em uma galeria na Virgilio de Carvalho. Não. Trata-se da Galeria Jaqueline Martins. Tenho trabalhado bastante nesses dias, e quase não encontro tempo pra mais nada. 
Ah! Talvez você já tenha visto. Estou no momento participando da exposição sobre as performances dos anos 80 na Pinacoteca (na foto anexa, Gabi \& eu, nos depoimentos em vídeos). Eles andaram organizando uma série de palestras, sempre às quintas-feiras. Numa delas, a palestrante foi a Daria Jaremtchuck, que falou sobre os anos setenta, e fez largas referências aos nossos trabalhos daquele período, com projeção de fotos no telão ("A Cerca da Natureza”, nas rampas do MAC). Muito obrigado por tudo. Encaminhei seu e-mail para Lydia \& MariOlimpia também.

Grande beijo,

$G$

De: Gabriel Borba

Data: 18 de agosto de 2011 15:32:36 BRT

Para: grazi

Assunto: Re: valeu!

gostei de ter estado lá. No dia seguinte conversei com o Tadeu sobre você e sua perfornance.

Agradeço o texto e quando chegar a hora comento. O ideal seria uma conversa entre nós e mais quem você propuser.

Gostarei muito de ter uma cópia da documentação que vocêfez no meu ateliê. Ou parte dela...

A Adriana é estagiária da Cristina Freire. Mandarei para a Cris com cópia para Adriana.

Gabriel 
De: Luiza Proença

Data: 18 de agosto de 2011 16:15:33 BRT

Para: grazi

Assunto: Re: texto da fala

oi Grazi,

muito obrigada por me enviar o texto! enviei também ao grupo, junto com seus agradecimentos.

Hoje na nossa reunião falaram muito da sua fala e gerou uma discussão bastante bacana. O pessoal achou importante te trazer pra falar, mas sentiram muito a falta de entender melhor afinal qual era o seu trabalho (aquilo que eu te disse que seria legal você mostrar no mínimo uns 3 trabalhos da sua trajetória, dado que no encontro tem muitos iniciantes em artes e que também o Tadeu não conhece). Tive a impressão de que a apresentação focou no seu interesse em doar as obras (o que eu tinha alertado pra você ser sutil nesse momento), sendo que o pessoal nem sabia o que eram as obras (o objetivo dos encontros), e isso gerou um pouco de confusão.

Mas eu preferiria depois conversar disso com ve com calma.

um beijo!

Luiza

De: Jaqueline Martins

Data: 18 de agosto de 2011 16:32:15 BRT

Para: grazi

Assunto: Genilson

Oi Graziela, tudo bem?

Sou galerista e estou honradamente trabalhando com o Genilson na galeria.

Em outubro tem exposição aliás!

O Genilson me encaminhou o texto que você escreveu tema da palestra ontem no MAC, belíssimo texto, Graziela, parabéns! 
Uma pena não ter ido, eu não sabia se soubesse teria ido com certeza! Bom é isso, escrevi pra te dar parabéns e convidar pra conhecer a galeria Rua Dr Virgílio de Carvalho Pinto, 74.

BJ

Jaqueline

De: grazi

Data: 18 de agosto de 2011 19:43:48 BRT

Para: Luiza Proença

Assunto: resposta ao grupo

Oi Luiza, que pena. Estava aguardando ansiosamente o seu retorno e fico muito triste que o pessoal tenha sentido dessa forma.

Entendo o texto e a leitura do texto como um trabalho meu... Além disso, durante o debate foi possível falar sobre alguns projetos meus, até mesmo mais de três. É engraçado porque no texto eu faço justamente uma crítica sobre a forma como o artista é reduzido a suas obras. Citei uma fala linda do Zanini, quando ele compara o artista a um pássaro e diz que os museus não deveriam dar atenção somente aos ovos desse pássaro, mas fundamentalmente ao seu vôo.

Sobre a doação, eu não tinha como não falar disso, pois é ou ao menos era verdade. Desde o começo do ano venho pensando nisso. O MAC não é somente esse momento, o MAC é toda uma história. Você me fez a pergunta "O que você espera do MAC" e foi assim que respondi. Espero um museu que trabalhe em colaboração com o artista, com esse artista vivo ainda, no processo de conservação e de tornar pública sua obra da melhor forma possivel. Espero também um MAC que assuma sua responsabilidade histórica. Francisco Iñarra morreu pobre, muito pobre mesmo. Sequer tinha dinheiro para pagar um ônibus entre Diadema e São Paulo. Foi um dos artistas mais incríveis da história do MAC e da Bienal e me pergunto se a aquisição de obras/documentos dele não teria sido mais bacana do que adquirir obras de alguns dos 
jovens artistas já escolhidos. Foi esse tipo de dúvida e reflexão que quis compartilhar com vocês.

Em tempo, você cita o pessoal iniciante em artes. Quatro alunos do primeiro ano da ECA foram falar comigo na mesa no final e sabe o que eles me disseram? Primeiro, que viveram uma experiência incrível naquele auditório, que, para eles, naquele dia foi um auditório inteiramente novo, que estavam acompanhando todos os encontros e nunca tinham vivido nada igual ali. Em segundo, que eu havia me tornado uma artista de referência para eles. Eu talvez tenha sido dura com o menino que fez a primeira pergunta, que queria que eu explicasse o trabalho do Francisco e do Genilson no telão (na hora não percebi que fui dura, o Dani é que me alertou disso). Mas foi porque, ao invés de dar respostas a ele, eu queria que ele se esforçasse para buscar um sentido naquele diálogo indecifrável. Eu acho que não entender as coisas faz parte do processo de aprendizado; que talvez a gente aprenda muito mais com as coisas que escapam, que a gente ainda não entende, do que com os comportamentos esperados.

Agradeço se puder encaminhar esta resposta ao grupo e agradecer a todos novamente - foi muito intenso para mim. Coloco-me desde já à disposição para recebê-los aqui em casa ou ir até vocês para mostrar alguns dos meus trabalhos ao vivo, até mesmo as gravuras em metal das quais não tenho uma foto sequer.

beijos, grazi

De: Jorge Menna Barreto

Data: 18 de agosto de 2011 21:30:41 BRT

Para: grazi

Assunto: Re: para você ler...

nossa, grazuka, fiquei chocado com esse email! 
seu trabalho não é sua obra, mas seu jeito de pensar, e isso está abundante no seu txt e projeção! as "obras" são alguns momentos, dos muitos outros possíveis, de tornar público um fluxo de pensamento. e o mais legal numa palestra é ter contato vivo com esse fluxo, pois dai a palestra se torna a obra, e não é sobre a obra. e para mim, qndo vc projeta aquela imagem, já anuncia que esta palestra não é sobre o seu trabalho, mas o próprio trabalho...

me preocupa muito tb grazuka essa posição de insatisfação e uma análise negativa do que a sua palestra NÃO foi... como se tivesse sido ineficiente, ou não tivesse "funcionado", verbo que tanto me incomoda quando aplicado ao pensamento artístico, vc sabe. muito triste mesmo, grazuka. gostaria de conversar mais com ve sobre isso... andei pensando umas coisas sobre a ascensão desse pensamento ultraconservador e eficiente, que se encaixa perfeitamente em uma demanda institucional de uma suposta criticidade.

grazuka, temos que continuar trabalhando e fazendo o que fazemos. agora me ocorre que essa seria uma resposta possível para a luiza, dizendo pra ela que esse tipo de desencaixe entre a proposição e sua recepção não é uma novidade pra vc, que isso alimenta o seu trabalho e, mais do que ser analisado como um cumprimento ou satisfação das expectativas dos propositores ("o objetivo dos encontros"), que desviam a atenção do que foi produzido, está muito além do objetivo. acho que tô falando de inconformidade. vamos conversar mais sobre isso. beijo e, de novo, parabens pela palestra. hj lembrei do seu txt varias vezes durante o dia. para mim, foi um presente.

smack, jorge 
De: Ana Leticia Fialho

Data: 18 de agosto de 2011 21:32:33 BRT

Para: grazi

Assunto: Re: O MAC Encontra os Artistas, com GRAZIELA KUNSCH Grazi!

Que lindo! obrigada por compartilhar! tornaste tua fala em mais um trabalho, e um trabalho muito especial, emocionante!

Acho que essa reflexão merece ser publicada... eu mesma gostaria de usar em alguma aula, posso?

beijos (ainda com olhos úmidos)

Leti

De: Eduardo Costa

Data: 20 de agosto de 2011 11:09:13 BRT

Para: grazi

Assunto: txt MAC

grazi,

acho a sua 'performance' - se podemos classifica-la assim - / texto muito interessante. gosto de alguns trechos em especial.

vou comentando certas questões ao longo da minha leitura... dentro do que posso contribuir.

quase no fim da segunda página, você fala que o próprio Donato comenta sobre uma 'falha' na documentação do seu próprio trabalho. o que você mesma parece encontrar em seu trabalho. acho que esta questão é fundamental dentro da própria lógica / ação política daquele (daqueles) que constrói o (seu) arquivo, na medida em que articula 'memória - esquecimento’. palavras que são indissociáveis, principalmente, neste caso.

continuando: sobre negociações entre mac e artistas, você fala que desconhece... mas não seriam estes encontros um espaço de negociação? eu acho que sim. como conversamos quarta, o arquivo / acervo não é 
propriamente - ou simplesmente - seus documentos, suas obras, mas aquilo que se constrói em torno dele, aquilo que se constrói sobre. acho que estes encontros são sim o próprio museu. certamente o encontro foi gravado e, agora, se encontra um registro disso no interior do museu. na medida do possível - e com o tempo - isso vai sendo revelado por outros, por outras ações. como me parece que o Donato vem sendo revelado por você, pois há uma evidência - muito clara - da sua presença no museu e uma importância. o que apaga (ou esquece) - eventos, documentos - é uma decisão política do museu e daqueles que ofazem... dos seus guardiões. por isso, tadeu chiarelli é hoje um homem forte no campo da arte contemporânea. ele tem grande poder de decidir sobre o que esquecer e o que recordar no interior do MAC - uma instituição pública, como você destaca. por isso, acho muito bom quando você chama a responsabilidade para o museu. não especificamente sobre o que ele vai colecionar, mas sobre o que ele vai construir e como? qual é a instituição museu - MAC?

destaco: não há como recordar ou esquecer tudo. trata-se sempre de um jogo político, da construção de uma instituição (a do MAC). veja, a própria seleção dos artistas para este encontro já é uma decisão. poderia ser uma grande assembléia entre artistas e museu. algo - teoricamente - mais democrático.

bom, eu não sei muito sobre questões ligadas à arte. mas tem uma questão bem interessante sobre o Projeto Matéria, que você cita. interessante pois o próprio projeto parece se relacionar com a noção de museu / arquivo. quando vemos uma obra de arte no interior de um museu, vemos - em seu limite clássico - um objeto autônomo, que a princípio acaba em si mesmo e adquire - com o tempo - uma autonomia a partir do momento de sua finalização. autonomia conquistada pela presença em mostras, pela citação de críticos, pela sua restauração... na medida em que não se produz um objeto, a única coisa que nos resta é o arquivo daquele 'objeto' (o making of, talvez). com isso, não estamos tratando do objeto clássico da arte, mas com suas entranhas, com o seu arquivo, 
o seu projeto. por isso, acho que deveria-se preservar o arquivo deste projeto. questão que parece muito se relacionar com o seu trabalho e com a própria dinâmica de construção de uma instituição.

veja: como preservar algo que se relaciona a uma ação de negativação? como a demolição da antiga rodoviária? não dá para preservar a demolição, nem a antiga rodoviária. só restam as evidências desta ação, seus documentos, seu arquivo.

conheço os diretores do arquivo do estado do rio e de são paulo. eles conseguiram recentemente verbas do estado, pois souberam bem demonstrar - convencer - os respectivos governadores de que o arquivo público é responsável pela manutenção das idéias do estado. assim, não há como manter uma idéia de estado - uma política - sem manter a força de um arquivo. o que vale para o MAC e qualquer instituição pública.

bom, sabe que este tema muito me move. gostei da sua intervenção. quem sabe da próxima vez não acontece a assembléia. como nos espaços negociados durante a JAC 72.

e acho sim que foi uma performance.

eduardo costa

De: Vitor Cesar

Data: 25 de agosto de 2011 19:26:28 BRT

Para: grazi

Assunto: Re: texto do MAC

oi grazi,

não aguentei esperar e fui ler teu texto antes de responder! :)

é lindo e emocionante para mim, não existiria forma melhor de mostrar como a artista (grazi) trabalha, como se posiciona, em que acredita, como se movimenta no circuito. enfim, é um trabalho mesmo, dos muito bons! e como tu escreve bem! eras...

olha, vou transcrever um trecho do eduardo viveiros de castro que me 
parece mais organizado sobre a noção de simetria do latour.

"A questão que Latour coloca é o que significa fazer antropologia na nossa própria sociedade, questão que ricocheteia sobre o modo de fazer antropologia em outras sociedades. Como fazer uma antropologia simétrica? Ou como simetrizar a antropologia? A noção de antropologia simétrica é alvo de todo tipo de mal-entendido porque a palavra simétrica quer dizer muitas coisas diferentes. Quando Latour diz "simétrica", o que ele propõe é a dissolução de assimetrias constitutivas do pensamento antropológico, pensamento cuja forma emblemática é a assimetria entre o discurso do sujeito e do objeto. Assim, é contra essa assimetria que a noção de simetria é proposta. Ninguém está propondo um mundo onde tudo seria harmônico e igual! $O$ oposto do grande divisor não é a unidade e a noção de simetria não vai restaurar nenhuma unidade perdida. O que se contrapõe aos grandes divisores são as pequenas multiplicidades. A noção de multiplicidade é chave: o problema não é ser dois, mas ser só dois; e a solução para isso não é voltar ao um".

no mais, as coisas estão muito inseridas no texto e não faz muito sentido se eu selecionar trechos.

ah, te mando também em anexo o que fiz na tatuí.

$B J S$

Vitor

De: Karen Montija

Data: 29 de agosto de 2011 00:56:33 BRT

Para: grazi

Assunto: Re: emails

Oi Graziela,

em vários momentos seu texto me atingiu. Oras por me ensinar um dado importante, uma visão, ora por indiretamente me questionar sobre o que faço e porque faço! 
O que ouvi no auditório foi muito instigante e provocador para mim. Tem duas coisas que não consegui parar de pensar...

A primeira tem a ver com minha formação mesmo... e sobre todas as questões que você levanta ao longo do discurso. Questões ainda confusas na minha cabeça e que me dão a sensação de falta de repertório sobre o assunto. Apesar de ter sido estagiária do MAC por dois anos, ter trabalhado com educação em museu por três, a sensação ao longo do texto era... "quero saber mais... o que mais aconteceu nesse período? lá pelas rampas do MAC... por favor, não deixe de contar as tais histórias"...

A vontade de saber mais, somada às próprias questões do papel do museu, que me inquietaram. Porém, a segunda coisa que não parei de pensar foi mais forte!

Enquanto você falava sobre preservar sua obra, e como o museu poderia exercer este papel, muito me perguntei sobre o que estou fazendo. Sentimento comum entre artistas que ainda estão "caminhando" e que muitas vezes se questionam se o que fazemos é relevante! enfim, inseguranças que surgem com certa frequência, e sei que não só comigo! Mas confesso que no momento em que ve disse no encontro: "Olho para algumas obras e questiono se colaboram para fazer avançar a história da arte..."; decidi algo em minha vida!

Neste mesmo dia, a galeria que sou membro (e não serei mais num futuro próximo), havia entrado em contato para eu participar de uma expo coletiva em Milão. Eles levariam duas fotografias.

Quando vc disse essa frase eu percebi o quanto não queria participar disso! Por várias razões... esta galeria, apesar de ter sido importante em determinado momento, eu nunca me encontrei nela! Ela tem a visão comercial para o público interessado especialmente em decoração, e na maioria das vezes sem qualquer critério! Depois vi a mesma galeria divulgando em redes de relacionamento na internet que estava selecionando artistas para esta exposição em Milão. Quem pagava, entrava! Bom, sei que estou aqui desabafando coisas - um pouco jogadas - mas 
quando vc citou o Prof. Alexande Mate (infelizmente, não tive o prazer de ter aula com ela lá na Unesp, mas muitos citam frases dele, impressionante!), achei que poderia ser interessante para você saber que talvez um dia direi: "Vou citar agora a Graziela que foi minha professora..."! (rs).

Como realmente pequenos atos e pequenas coisas, às vezes, sem a pretensão de ser, modificam e encorajam toda uma vida!

Também aproveito para me desculpar, pois sinto que talvez tenha te frustado, quando não apresentei para a sala meu projeto em andamento na última sexta. Mas fato é que vc me incentivou e sim, eu caminhei com ele, mas não poderia já ir para rua com os acetatos, pois ainda tem coisas a acertar!!

Enfim Graziela, desculpe por este longo email, mas achei que cabia lhe contar o quanto estou inspirada a seguir e não desistir, apesar de pelo menos uns 8 ou 9 editais não aprovados de bagagem! E esta crença renovada se deve muito a sua presença neste momento que estou passando.

Muito grata,

Karen Montija 
Um amigo comentou comigo que Rodrigo Siqueira teve bastante dificuldade para montar o documentário Orestes. Assisti ao filme no sábado, no festival É tudo verdade, e, emudecida, senti-me mobilizada a escrever sobre ele. No processo de redação percebi que mesmo que o filme proponha uma estrutura por capitulos, intitulados objetivamente com nomes como "Traição" e outros, sua ordem não é muito clara para mim, prevalecendo certa confusão entre as diferentes camadas que o compõem - entrevistas, sessões de psicodrama e um julgamento simulado, entre outras. Tudo isso para dizer que tive enorme dificuldade em organizar a escrita e que precisei recorrer à descrição de cenas em muitos momentos; mais descrição do que eu gostaria. Queria evitar muitos spoilers, mas não consegui. Quem já tiver visto o filme e quem não tiver problema com isso, está aí! Ainda devo mexer um pouquinho, corrigir eventuais erros ou imprecisões, mas está aí! Não pude ver o filme vencedor do Carlos Nader sobre o Leonilson e confio que deva ser lindo. Mas torci pelo filme do Rodrigo ${ }^{32}$.

\section{O sentido da tela preta em Orestes, de Rodrigo Siqueira}

Há um momento crucial no final de Orestes (Rodrigo Siqueira, 2015), que, no entanto, é tão somente uma tela preta. Nesse momento, de ausência de imagem, o filme sai da tela e implica toda a sala de cinema nele. O filme nos convoca, espectadores, a tomar partido no julgamento de um homicídio que nunca aconteceu, a não ser como história ficcional. E deliberar sobre esse assassinato hipotético significa nos posicionarmos sobre uma série de outros assassinatos; estes reais e impunes ${ }^{33}$.

\footnotetext{
${ }^{32}$ Post público de 21/04/2015 no meu mural de Facebook, anunciando crítica publicada no naocaber.org.

${ }^{33}$ Em janeiro deste ano, 2015, policiais foram julgados e condenados pelo assassinato do filho do personagem Daniel Eustáquio de Oliveira, ocorrido em 2012, mas durante a realização do filme o caso permanecia impune. Para mais informações sobre o caso ver http://ponte.org/pms-presos-apos-pai-devitima-investigar-execucao-sao-julgados/ . Último acesso em 18/3/2016.
} 
Entre os muitos assassinatos reais abordados no filme dois ganham destaque. Primeiro, o sucedido com Soledad Barret Viedma, torturada até a morte em 1973, quando estava grávida de quatro meses, tendo sido denunciada por Cabo Anselmo, pai do bebê que ela esperava. Ele havia se envolvido com ela forjando ser alguém que não era, sendo na verdade um espião do Estado brasileiro infiltrado em uma organização de luta armada. Segundo, a morte de um rapaz, há poucos anos, cujo nome eu não guardei e que provavelmente não será facilmente localizado em buscas de internet, como é o caso de Soledad. Dele só retive uma imagem descrita por sua mãe, Eliana Nascimento, de que tinha uma pinta no pescoço. Foi através de uma fotografia e da constatação dessa pinta no pescoço que sua mãe pôde confirmar sua morte, sem poder, no entanto, enterrá-lo. Ele já havia sido enterrado, como indigente, no cemitério de Perus. Consta (da fala oral de policiais) que ele teria resistido a uma ordem de prisão e que por isso levou três tiros da polícia, sendo ao menos um desses tiros pelas costas.

Tomamos conhecimento desses e de outros casos em fragmentos de entrevistas individuais realizadas com os personagens do filme que, posteriormente, irão se encontrar em sessões coletivas de psicodrama ${ }^{34}$. Entre esses personagens estão, além de Eliana: Ñasaindy, filha de Soledad com José Maria Ferreira de Araujo, conhecido como Arariboia, militante da Vanguarda Popular Revolucionária (VPR) e assassinado em 1970 no DOI-Codi; José Roberto Michelazzo, preso e torturado no DOI-Codi; Marcelo Zelic, do grupo Tortura Nunca Mais; Sandra Domingues, defensora da pena de morte; Maria Dias, enfermeira de um hospital público de periferia que atende muitas vítimas de violência por arma de fogo; Adilson Pires de Souza, policial; e Marisa Greeb, psicodramatista responsável pela condução da experiência.

\footnotetext{
${ }^{34}$ No caso de Soledad, além da entrevista com sua filha o diretor usa o recurso de registrar buscas sobre o caso na internet, incluindo um trecho do programa Roda Viva no Youtube, que tem Cabo Anselmo como entrevistado.
} 
O primeiro encontro do grupo acontece no DOI-Codi e já na roda de apresentação ocorre uma tensão. Quando Eliana se apresenta, ela é interpelada por Sandra, que veste uma camiseta escrito "JUSTIÇA" em letras bem grandes. Sandra pergunta se o filho de Eliana estaria armado no momento de sua morte; insinuando que, se estivesse armado, poderia tirar a vida de muitos inocentes e que sua morte se justificaria. Esse tema se estende para o segundo encontro do grupo, nas ruínas do teatro $\mathrm{TAIB}^{35}$, e cumpre no filme o papel de trazer para o presente os desaparecimentos/assassinatos cometidos por militares no período da ditadura e a anistia a eles concedida. A diferença é que hoje as principais vítimas da Polícia Militar e do Estado não são intelectuais ou militantes de esquerda (ainda que militantes de esquerda continuem sim sendo perseguidos, presos e torturados), mas jovens negros e pobres moradores das periferias e favelas. Após esse aquecimento entre os personagens do psicodrama e a exploração desse tema o filme inicia um novo movimento, com outras pessoas e em outro espaço, que irá tratar do assassinato cometido por Orestes, personagem de ficção que dá nome à obra ${ }^{36}$. No salão nobre da Faculdade de Direito do Largo São Francisco, um juiz dá início a um julgamento simulado do crime de Orestes e informa que todos os presentes - a plateia está lotada - irão compor o júri do caso.

Orestes era filho de Maria do Socorro, que havia participado da luta armada contra a ditadura no Brasil. A primeira vez que Orestes viu seu pai, Gilson, foi aos seis anos de idade, no momento em que este matou sua mãe, por estrangulamento. Gilson fora amante de Maria do Socorro, na condição de espião infiltrado. Trinta e sete anos após ver seu pai

\footnotetext{
${ }^{35}$ Teatro localizado no subterrâneo da Casa do Povo, no Bom Retiro, que foi um reduto de intensa atividade contra a ditadura militar.

${ }^{36}$ Inspirado na tragédia "Oréstia", de Ésquilo, na qual Orestes é absolvido de ter matado sua mãe para vingar a morte do pai. A referência é descrita logo no primeiro letreiro do filme (posteriormente espero publicar o parágrafo de descrição aqui).
} 
matar a sua mãe, Orestes viu Gilson dando uma entrevista em um programa de televisão e foi em busca do pai, desarmado. No encontro, acabou estrangulando seu pai e, de acordo com o promotor do caso, bateu a cabeça do pai repetidas vezes contra o chão.

Ao fundo da plateia-júri vemos uma faixa contra a anistia concedida a torturadores, que funciona como elemento de realidade em meio à situação construída e nos informa que aquela encenação é, também, um ato político. A força retórica dos discursos tanto do promotor como do advogado de defesa impressiona: fica claro que eles não estão declamando um texto previamente escrito ou decorado, mas improvisado, um escutando e contra-argumentando o outro. Essa aposta na oralidade improvisada (que não pode ser controlada pelo diretor, a não ser parcialmente, no processo de montagem), tanto no julgamento simulado como nas sessões de psicodrama é, ao mesmo tempo, o aspecto mais documental e mais teatral do filme. Se há ali uma fusão entre ficção e documentário, ela se dá muito mais por essa qualidade cênica - que remete a filmes como Salve o cinema ${ }^{37}$ - do que pelo paralelo entre a história inventada de Orestes e a história real de Soledad.

De maneira surpreendente, aos poucos esses dois movimentos documentais e teatrais (o julgamento simulado e o psicodrama) irão se misturar. O réu confesso na ficção, Orestes, está ausente de seu julgamento, mas acabará encarnado por Ñasaindy e José Roberto Michelazzo, no último exercício de psicodrama.

A sequência começa com a enfermeira Maria narrando a história de Orestes para aqueles que haviam faltado no encontro anterior. Con-

\footnotetext{
${ }^{37}$ Filme de Mohsen Makhmalbaf que integra a lista de filmes desta pesquisa. Há um pequeno texto meu sobre a noção de chorar de verdade neste filme no naocaber.org: http://www.naocaber.org/o-chorar-de-verdade-de-salve-o-cinema/ .
} 
forme a história de Orestes avança, Ñasaindy começa a chorar, ao perceber o paralelo óbvio entre Maria do Socorro e sua mãe, Soledad. De maneira bastante amorosa, a psicodramatista Marisa pergunta se Nasaindy quer compartilhar o que está se passando com ela com o grupo. Aos poucos ela começa a revelar a sua história de vida, sofrendo por ter imaginado como seria se fosse filha de Cabo Anselmo, assim como Orestes é filho de Gilson. Marisa então pergunta se ela gostaria de encontrar Cabo Anselmo, para perguntar coisas diretamente a ele. E se por um pequeno instante imaginamos que o filme vá tentar promover um encontro real entre Ñasaindy e Cabo Anselmo, logo presenciamos um encontro também muito real, mas na forma de improvisação teatral.

Nasaindy sobe as escadas do teatro TAIB e ali encontra Marcelo ZelicCabo Anselmo. Ele é grosso e impaciente com ela, mesmo após saber que ela é a filha de Soledad. Ela pergunta a ele se ele amou Soledad. Marcelo não dá espaço para qualquer romantismo ou complexidade em sua interpretação, insistindo somente na faceta de carrasco insensível de Cabo Anselmo, deixando Nasaindy com cada vez mais ódio dele. Aos poucos ela consegue dizer, repetidas vezes, o que possivelmente passou mais de trinta anos entalado: "Você é um covarde". Nasaindy e Marcelo-Cabo Anselmo são surpreendidos com uma entrada brusca do participante José Roberto-Orestes em cena, que termina estrangulando Gilson-Cabo Anselmo. A improvisação cresce em dramaticidade com o suporte de uma música/trilha sonora, inserida na montagem. Nós já não vemos Anselmo no enquadramento, mas Ñasaindy assistindo à cena.

Será que vê-lo sendo estrangulado a ajuda a superar sua dor, seu trauma? Não sabemos. Em meio a essa dúvida - talvez antes, talvez depois, já não me recordo ao certo - acontece a fala final do advogado de defesa de Orestes. Eu aguardava ansiosamente a cena em que a mul- 
tidão presente no salão iria decidir sobre a sua absolvição ou condenação (seria uma cena previamente ensaiada? as pessoas se posicionariam de improviso, durante a gravação, levantando seus braços? haveria debate, ou mesmo conflito?), até perceber que essa cena não iria existir. A multidão éramos todos nós e esse debate teria que se dar para além da exibição do filme no festival É tudo verdade.

Nós espectadoras e espectadores somos implicados no documentário; a história das vítimas da ditadura e da violência policial/estatal é também a nossa história. A prevalência da anistia a torturadores e a impunidade concedida a policiais militares e estadistas que diariamente matam jovens negros e pobres também nos diz respeito. $\mathrm{O}$ uso recorrente da tela preta em muitos cortes do filme, que inicialmente causa um pouco de desconforto e estranhamento, nesse momento se enche de sentido. A plateia-júri já não está lá porque a verdadeira plateia somos nós, na sala de cinema transformada em uma extensão do salão nobre da Faculdade de Direito e do teatro TAIB.

Há um momento no filme em que a enfermeira Maria afirma que não se pode compreender verdadeiramente uma dor estando fora dela. Mas por meio da arte isso talvez seja possível. A obra de Rodrigo Siqueira nos convoca a sentir essa dor. 
Comentário público do Rodrigo Siqueira no post público de Facebook: Graziela Kunsch, fico feliz que ofilme tenha lhe implicado algum sentido de urgência em escrever. E agradeço a torcida. Mas, como realizador, acho chato contar o final de um filme que está apenas começando a ser mostrado. E isso é o de menos, já que vai "descrever” o filme, o faça com precisão. Você descreve elementos na cena final que não existem.

Minha resposta a ele, por chat:

Oi Rodrigo,

me desculpe. Hoje eu havia incluído a mensagem de "Contém spoilers" antes do primeiro parágrafo. Escondi o post aqui no Facebook e tornei o texto privado (inacessível). Não era a minha intenção original ter antecipado o filme, mas o processo de escrita foi penoso e o texto só nasceu assim.

Sobre os erros na minha descrição, você pode me apontar quais são, de modo que eu possa revê-los? Será a própria tela preta, que me fez querer escrever? Será a ordem dos fatos, que na minha percepção se misturaram um pouco? A música? Será quando digo que "Aguardamos o julgamento"? Ali eu é que aguardava esse momento, pensando que haveria uma cena da plateia deliberando sobre o caso. Essa frase pode ser mais trabalhada por mim. Como afirmei no meu post do Facebook, eu ainda gostaria de corrigir erros e imprecisões. Mas para isso terei que ver o filme novamente e estudá-lo. De todo modo eu gostaria de deixar claro que essa confusão que aparece no final do meu texto reflete o modo como percebi todo o final do filme.

Mas não se preocupe, por enquanto o texto vai permanecer inacessivel. Talvez eu coloque acessível para quem tiver uma senha, para poder compartilhar com amigos depois que o filme estiver um tempo em cartaz. Fico realmente triste que tenha causado esse desconforto para você. 
Minha resposta pública a ele, no post de Facebook:

Oi Rodrigo, obrigada pelo retorno crítico. Tão logo li seu comentário tornei privados o post aqui no Facebook e o texto, e te escrevi individualmente para me desculpar pelo desconforto causado e perguntar que elementos abordados na minha crítica não existem no filme. Após um longo mal estar, tomei a decisão de colocar este post novamente no ar e de tornar o texto acessivel mediante uma senha, ao menos por enquanto, que poderá ser solicitada a mim por amigos ou leitores do meu site. Do mesmo modo que o filme foi tornado público no Festival É tudo verdade, que a minha pequena crítica foi tornada pública no naocaber.org e que seu comentário para mim foi no modo público aqui do Facebook, achei que deveria também respondê-lo publicamente. Essa talvez seja a tarefa mais importante da crítica: suscitar debates públicos; proporcionando outras formas de existência de uma obra de arte, para além dela mesma e do controle de seu realizador. Sobre os spoilers presentes no meu texto, entendo que toda crítica sobre um filme, em alguma medida, contém spoilers. Pessoas que, como eu, têm problemas com spoilers, não lêem as críticas existentes sobre um filme antes de vê-lo. Ou, se começamos a ler e percebemos que há spoilers, interrompemos imediatamente a leitura. Tapamos os ouvidos se alguém for comentar o final de um filme que ainda não vimos. Mas há também pessoas diferentes de mim, que não têm isso como uma questão. E as muitas pessoas que já terão visto o filme antes de ler. Somente no É tudo verdade, foram quatro sessões quase lotadas, em São Paulo e no Rio de Janeiro. Eu ficaria contente que essas pessoas pudessem ter acesso ao meu texto ao buscarem críticas sobre o mesmo na internet, especialmente considerando que o texto mais visivel e lido sobre o filme deve ser a crítica de Cássio Starling Carlos publicada na Folha de S. Paulo, que atribuiu uma única estrela ao seu trabalho. Sobre a falta de precisão na minha descrição da sequência final, estou disposta a revê-la. Fiquei na dúvida se o meu erro está na afirmação de que há uma tela preta em dado momento, que foi justamente a minha 
inspiração para escrever, mesmo sabendo que o uso da tela preta é recorrente ao longo de todo o filme. Ou se errei na ordem em que apresento os fatos, na forma como comento o uso da trilha, ou mesmo na frase "Aguardamos a multidão presente no salão decidir sobre a sua absolvição ou condenação", entre outras possibilidades. Se for a frase, em verdade era eu, como espectadora, que aguardava como seria o momento de deliberação do júri, até mesmo imaginando se a cena teria sido ensaiada previamente ou se as pessoas decidiriam no momento da gravação, levantando seus braços. Como te disse em mensagem privada, posso trabalhar mais essa frase, assumindo a primeira pessoa singular no lugar da primeira pessoa do plural ou, se o problema não estiver aí, reparar o que estiver equivocado. Mas preciso dizer que fiquei decepcionada de ouvir do realizador de um filme que em diversos momentos borra os limites entre fantasia e realidade que falo de elementos que não existem. Se escrevi sobre eles, foi porque existiram para mim. Descrever um filme não é somente descrever fatos objetivamente; é, antes, descrever a nossa experiência diante dele, descrever a nossa percepção subjetiva. No processo de realização do seu filme você generosamente aposta na improvisação e na oralidade de seus personagens, mas quando o filme começa a circular e alguém se dispõe a escrever sobre ele você quer controlar como isso deve ser feito? Está no seu direito de realizador, mas também quero defender meu direito como espectadora. Escolhi escrever sobre o filme após uma única mirada porque, como você mesmo afirmou, senti essa urgência ao me deparar com a sua obra. O que de fantasia ou de confusão foi produzido pela minha emoção eu não sei medir, mas reflete a forma como vi o final do filme. Eu entenderia a sua imposição para mim ("já que vai 'descrever', o faça com precisão”) se eu tivesse feito uma crítica irresponsável ou preguiçosa, mas acho que quem chegar a ler o texto poderá constatar que não foi o caso, que houve dedicação ali. Foi inclusive um processo penoso, porque inicialmente eu não planejava escrever e não tomei notas durante a projeção. Reforço que se houve 
erros grosseiros ou mesmo pequenos erros irei tentar repará-los tão logo tiver novo contato com a obra ou puder ouvir novamente de você. Mas quero assegurar o meu direito a uma percepção subjetiva diante de uma obra de arte; especialmente uma obra que, a todo momento, problematiza o que tomamos por verdade.

Comentário público de Kiko Dinucci, no post de Facebook:

Quero ver o filme, quero ler o texto. Gosto mais dos filmes que dos finais dos filmes. Se formos pensar no sentido da crítica, ela é para ser lida depois de assistirmos o filme, dessa maneira os spoilers são indiferentes. Os jornais nos ensinaram o contrário, fazem uma resenha rápida, quase uma sinopse, dizem quais prêmios o filme ganhou ou se o filme é bom ou ruim e dessa maneira promovem ou arruinam um filme. As pessoas consultam esses textos antes de ir ao cinema e já vão com uma opinião pronta sobre o filme antes de ve-lo e isso acontece sem spoilers. Pode ser bom ou ruim para a divulgação do filme, mas geralmente é ruim para a crítica. Sempre que divulgo os textos do meu blog O Olho Derramado, digo aos leitores para assistirem o filme antes de lerem o meu texto. E sempre digo a frase: que o público assista o filme e leia posteriormente a crítica com a mesma severidade com que o critico analisou o filme. O meu lado metido a crítico diz que é impossível analisar um filme sem arrancar as suas entranhas, sem expô-las aos leitores. Todos os meus textos são spoilers se forem lidos antes de assistir a obra. 
Retorno de Rubens Machado Jr., por email:

Oi Grazi,

As descrições estão muito, muito boas! Li também as suas críticas sobre os dois filmes iranianos. Os textos nos colocam diante dos filmes, o que diz respeito à estética que os próprios filmes mobilizam, além de contemplar uma atenção de espectador que sabe e quer saber tudo aquilo que figura no horizonte da produção de sentido. Pegam pelo elementar e pelo mínimo. É um bom caminho.

Retorno de Juçara Marçal, por chat:

muito legal a sua percepção dessa plateia expandida em q nos tornamos ao ver o filme. é isso mesmo q o filme provoca, né!? e não só em relação ao orestes fictício, mas diante de todas as posições $q$ nos são colocadas. um mosaico doloroso e mobilizador.

mas visshh maria! o "contém spoiler" é pouco! vc devia colocar "é um spoiler detalhadíssimo"!! hahahahahaha q memória!

e como assim!!!??? o meu amigo rodrigo tá louco?? o q me surpreendeu foi justamente vc descrever o filme com uma riqueza de detalhes $q$ me fez reviver o filme! super preciso e certeiro seu olhar!

Comentário público de Francis Vogner dos Reis, no post de Facebook: Li agora. Achei formidável. O texto faz a crítica do filme - no sentido de colocar em questão métodos, procedimentos e efeitos expressivos mas é também, ainda, um texto sobre a pedagogia do filme e da relação-interação filme com o nosso lugar de espectador. Você e o filme nos visa como espectador e cidadão. Adorei a clareza, o olhar e seu estilo. O seu pensamento e olhos atentos se parecem com o modo como você fala. Acho fundamental em qualquer texto, principalmente quando se relaciona com a arte, que não é só pensamento árduo, mas também uma experiência que implica um ponto de vista ético elou moral sobre as coisas. Adorei. Obrigado. 
Retorno de Patrícia Mourão, em chat privado:

oi, Grazi, gostei muito do texto, senti uma certa familiaridade com o seu modo de se aproximar do filme, como alguém implicada / interpelada, mas também alguém que se vê vendo.

gosto desse modo de aproximação e reconheço tbm a necessidade da descrição. sei que para alguns pode ser um excesso, mas lendo seu texto penso na importância que a descrição tem para mim, no meu processo de pensar sobre um filme.

em geral ela é uma espécie de guia das minhas reações... e tendo achar que o único lugar que posso ocupar ao falar de um filme é aquele de alguém que foi afetado por ele, jamais aquele de quem sabe algo sobre ele (porque de fato não acredito muito nisso, de saber algo sobre). sobre o debate nos comentários: não sei se perdi algo, mas acho que se para você o debate é importante e se o Rodrigo falou, com raiva ou não, não importa, para abrir o texto, você deveria abri-lo. A crítica não é o terreno do consenso, você está em um lugar e o cineasta está em outro, e é bom que seja assim; e acho vital que esses dois lugares sejam mantidos e respeitados mesmo com todo o atrito que possa surgir dele. Quando você retira o teu texto do acesso público, mas mantém o post, acho que você desloca a discussão para outro lugar; não mais um texto e um filme, mas duas opiniões, duas personalidades, dois argumentos. beijos! 
De: grazi

Data: 2016-03-15 22:03 GMT-03:00

Para: Rubens Machado Jr.

Assunto: estado atual

Oi Rubens,

com exceção de uma pequena passagem na pág. 30 que ainda preciso desenvolver, envio o que considero consolidado, até a página 43. Trabalhei mais toda a parte final da introdução e a parte 2.

Caso você tenha visto o que mandei ontem, há uma mudança significativa no final da parte 2. Talvez eu não use mais toda aquela parte que escrevi sobre o método de crítica, ou use isso somente na terceira parte ("a performance da crítica"), que antes eu queria que fosse formada apenas por textos + reações, sem nenhuma mediação (apenas texto $M A C+$ reações; texto Orestes + reações; e, em terceiro, uma provocação para a banca, à maneira de Nelson Leirner para Mário Pedrosa). Recentemente li um texto da Aracy que me chocou pelo conservadorismo, sobre o MASP, mas ali ela citou uma fala linda da Lina, que eu não conhecia ou não lembrava: "Minha preocupação básica foi a de fazer uma arquitetura feia (...). Quis fazer um projeto ruim e com espaços livres que pudessem ser criados pela coletividade”.

Talvez eu ainda use toda a parte sobre memória/rememoração/descrição/comentário/interpretação e eu como personagem da crítica, depois de MAC e Orestes. Eu vou continuar trabalhando e te mandar novamente tão logo eu julgar consistente.

Precisei mudar o corpo 11 para 12, por causa das normas. Também fui orientada a imprimir só frente, apesar de preferir o frente-e-verso.

Obrigada e abraço,

grazi 


\section{Bibliografia}

ADORNO, Theodor. O ensaio como forma. In: Notas de literatura I. São Paulo: Ed. 34, 2003.

ARFUCH, Leonor. O espaço biográfico: dilemas da subjetividade contemporânea. Rio de Janeiro: EdUERJ, 2010.

BARRETO, Jorge Menna. A sobrevivência do espanto. In: KUNSCH, Graziela (ed.). Revista Urbânia 5. São Paulo: Editora Pressa, 2014.

BAZIN, André. Montagem proibida. In: O cinema: ensaios. São Paulo: Brasiliense, 1991.

BERNARDET, Jean-Claude. Jogo de cena, 14/01/2008. Disponível no Blog do Jean-Claude, em: http://jcbernardet.blog.uol.com.br/ . Cineastas e Imagens do Povo. São Paulo: Cia. Das Letras, 2003. . Práticas documentárias e situações reais. Catálogo da exposição “A respeito de situações reais". São Paulo: EXO; Paço das Artes, 2003. Caminhos de Kiarostami. São Paulo: Cia das Letras, 2004.

CANDIDO, Antonio. O estudo analítico do poema. $4^{\text {a }}$ ed. São Paulo: Humanitas, 2004.

CARLSON, Marvin. Performance: uma introdução crítica. Belo Horizonte: UFMG, 2010.

CESAR, Marisa Flórido. Nós, o outro, o distante na arte contemporânea brasileira. Rio de Janeiro: Editora Circuito, 2014.

CLARK, Lygia. Nós recusamos. Texto de 1966 disponível na página online O mundo de Lygia Clark, da Associação Cultural O Mundo de Lygia Clark.

COHEN, Renato. Performance como linguagem. São Paulo: Perspectiva, 2004.

COMOLLI, Jean-Louis. Ver e poder. Belo Horizonte: UFMG, 2008.

DERTNIG, Carola; THUN-HOHENSTEIN, Felicitas (eds.). Performing the sentence. Berlim: Sternberg Press, 2014. 
CRAMEROTTI, Alfredo; SHEIKH, Simon (eds.). All that fits: The Aesthetics of Journalism. Derby: Quad Publishing, 2011.

DOUGLAS, Mary. Como as instituições pensam. São Paulo: Edusp, 1998.

FARIAS, Agnaldo. O fim da arte segundo Nelson Leirner. In: Nelson Leirner. Catálogo da mostra retrospectiva. São Paulo: Paço das Artes, 1994.

FELDMAN, Ilana. Na contramão do confessional. In: MIGLIORIN, Cezar (org.). Ensaios no real. Rio de Janeiro: Beco do Azougue, 2010.

FERREIRA, Gloria (ed.). Arte Contemporáneo brasileño: documentos y críticas. Santiago de Compostela: Artedardo, 2009.

FISCHER, Berit; KENDEROVÁ, Dorota; VARGA, Jaro (eds.). Revolution without movement: exhibition journal. Bratislava: HIT \& tranzit.sk, 2014.

FOUCAULT, Michel. The politics of truth. Los Angeles: Semiotext(e), 2007.

FREIRE, Cristina. Poéticas do processo: arte conceitual no museu. São Paulo: Editora Iluminuras, 1999.

. (org.) Walter Zanini - escrituras críticas. São Paulo: Annablume, 2014.

FREIRE, Paulo. Pedagogia da autonomia: saberes necessários à prática educativa. São Paulo: Paz e Terra, 1996.

GENETTE, Gérard. Discurso da narrativa. $3^{\text {a }}$ ed. Lisboa: Vega, 1995.

GLUSBERG, Jorge. A arte da performance. São Paulo: Perspectiva, 1987.

GOFFMAN, Erving. A representação do eu na vida cotidiana. $20^{\mathrm{a}}$ ed. Petrópolis: Vozes, 2014.

GRINOVER, Marina; RUBINO, Silvana (orgs.). Lina por escrito: Textos escolhidos de Lina Bo Bardi. São Paulo: Cosac Naify, 2009.

GUMBRECHT, Hans Ulrich. Produção de presença: o que o sentido não consegue transmitir. Rio de Janeiro: Contraponto/Ed. PUC-Rio, 2010.

JAMES, Gareth; ZEYFANG, Florian (org.). I said I love. That is the promise. The tvideo politics of Jean-Luc Godard. Berlim: B_Books, 2003. 
JOERES, Ruth-Ellen B.; MITTMAN, Elizabeth (org.). The politics of the essay: feminist perspectives. Bloomington: Indiana Univ. Press, 1993.

KIAROSTAMI, Abbas. A arte da inadequação. In: Folha de S. Paulo, Caderno Mais!, 17/10/2004.

KUNSCH, Graziela. Projeto Mutirão. Dissertação de Mestrado. Orientação do Prof. Dr. Rubens Machado Jr. ECA-USP, 2008.

. Depoimento. In: FERREIRA, Glória (org.). Anos 70: arte como questão. Catálogo de exposição homônima. São Paulo: Instituto Tomie Ohtake, 2009. p. 423

KUNSCH, Graziela; KELIAN, Lilian L’Abbate. Bastará que os educadores se interroguem. In: ENGUITA, Nuria et al (eds.). Como (...) coisas que não existem. Catálogo da 31 a Bienal de São Paulo. Fundação Bienal, 2014.

Rejeitados: amar é não caber. In: Liminaridade. Publicação independente de Núcleo Tríade e Coletivo Cartográfico, São Paulo, 2016.

Projeto Mutirão: um filme não realizável, uma prática documentária. In: Periódico Permanente, n. 6, 2016. Disponível em http://www.forumpermanente.org/revista/numero-6-1/conteudo/projeto-mutirao . Último acesso em $18 / 03 / 2016$

LASCH, Christopher. The culture of narcissism: american life in an age of diminishing expectations. Nova Iorque: Norton, 1991.

LEFEBVRE, Henri. La presencia y la ausencia: contribución a la teoria de las representaciones. Cidade do México: Fondo de Cultura Económica, 2006.

LEPECKI, André. Of the presence of the body: essays on dance and performance theory. Middletown, CT: Wesleyan University Press, 2004.

LINS, Consuelo. O documentário de Eduardo Coutinho. Rio de Janeiro: Jorge Zahar, 2004.

LINS, Consuelo; MESQUITA, Cláudia. Filmar o real - sobre o documentário brasileiro contemporâneo. Rio de Janeiro: Jorge Zahar, 2008.

LISPECTOR, Clarice. A paixão segundo G.H. Rio de Janeiro: Rocco, 1998. 
MACHADO, Arlindo. O filme-ensaio. Concinnitas (UERJ), Rio de Janeiro, v. 4, n. 5, 2003.

MACHADO Jr., Rubens. Das vagas de experimentação desde o Tropicalismo: cinema e crítica. In: IKEDA, Marcelo; LIMA, Dellani. (orgs.) Cinema de garagem. Rio: Wset, 2014.

. Análise da imagem movente: uma introdução às inquietações da crítica. Material das aulas de crítica do audiovisual na ECA-USP, não publicado.

MEIRELES, Cildo. Encontros: Cildo Meireles. Organização de Felipe Scovino. Rio de Janeiro: Beco do Azougue, 2009.

MIGLIORIN, Cezar (org.). Ensaios no real: o documentário brasileiro hoje. Rio de Janeiro: Beco do Azougue, 2010.

MÜLLER, Ulrike (ed.). Work the room: a handbook of performance strategies. Berlim: B_Books, 2006.

NICHOLS, Bill. Introdução ao documentário. Campinas: Papirus, 2005.

PEDROSA, Mário. Política das Artes - Mário Pedrosa. Organização de Otília Arantes. São Paulo: Edusp, 1995.

O corpo é a obra: conversa com Antônio Manuel, Hugo Denizart e Alex Varella. In: OITICICA FILHO, César (org.). Encontros: Mário Pedrosa. Rio de Janeiro: Beco do Azougue, 2013.

PRANDO, Felipe (ed.). Campo Neutral. Catálogo de exposição homônima, realizada no Museu da Gravura de Curitiba em 2013. Curitiba, 2014.

RAUNIG, Gerald; RAY, Gene (eds.). Art and contemporary critical practice: reinventing institutional critique. Londres: MayFlay, 2009.

RENOV, Michael. The subject of documentary. Minneapolis: Univ. of Minnesota Press, 2004.

ROLNIK, Suely. Arquivo para uma obra acontecimento. São Paulo: Edições SESC, 2011. 
RUBY, Jay. The image mirrored: reflexivity and the documentary film. In: ROSENTHAL, Alan (org.). New challenges for documentary. Los Angeles: Univ. of California Press, 1988.

SHEIKH, Simon. Representation, contestation and power: the artist as public intellectual. Republicart, 2004. Disponível em: http://www.republicart. net/disc/aap/sheikh02 en.htm. Último acesso em 18/03/2016.

SMALL, Irene. Live Streaming: on Documentary Strategies in Brazilian Art and Activism. In: Artforum, edição impressa de maio de 2014.

SMITH, Sidonie; WATSON, Julia (org.). De/Colonizing the subject: the politics of gender in women's autobiography. Minneapolis: Univ. of Minnesota Press, 1992.

STAM, Robert. O espetáculo interrompido: literatura e cinema de desmistificação. Rio de Janeiro: Paz e Terra, 1981.

Reflexivity in film and literature: from Don Quixote to Jean-Luc Godard. Nova Iorque: Columbia University Press, 1992.

STERRITT, David (org.). Jean-Luc Godard: interviews. Univ. Press of Mississippi, 1998.

TRILLING, Lionel. Sincerity and autenticity. Cambridge, MA: Harvard Univ. Press, 1972.

XAVIER, Ismail. O olhar e a cena - Melodrama, Hollywood, Cinema Novo, Nelson Rodrigues. São Paulo: Cosac Naify, 2003. . O discurso cinematográfico: opacidade e transparência. $3^{\mathrm{a}}$ ed. São Paulo: Paz e Terra, 2005. Indagações em torno de Eduardo Coutinho e seu diálogo com a tradição moderna. In: MIGLIORIN, Cezar (org.). Ensaios no real. Rio de Janeiro: Beco do Azougue, 2010.

. A teatralidade como vetor do ensaio fílmico no documentário brasileiro contemporâneo. In: Aniki: Revista Portuguesa da Imagem em Movimento. América do Norte, 1, jan. 2014. Disponível em: http://aim.org.pt/ojs/index.php/revista/article/view/52/19. Último acesso em 18/03/2016. 


\section{Filmografia}

*Aqui estou referenciando somente os dois filmes que receberam mais atenção ao longo da tese

Esperando Telê. Direção: Rubens Rewald e Tales Ab'Sáber (Brasil, 19932007). 90'

Orestes. Direção: Rodrigo Siqueira (Brasil, 2015). 93' 